\title{
0016-7037(95)00245-6
}

\section{Manganese and methane in hydrothermal plumes along the East Pacific Rise, $8^{\circ} 40^{\prime}$ to $11^{\circ} 50^{\prime} \mathrm{N}$}

\author{
Michael J. Mottl, ' Francis J. Sansone, ${ }^{1}$ C. Geoffrey Wheat, ${ }^{2}$ Joseph A. Resing, ${ }^{1}$ \\ EDWARD T. BAKER, ${ }^{3}$ and JOHN E. LUPTON ${ }^{4}$ \\ ' Department of Oceanography, University of Hawaii, Honolulu, HI 96822, USA \\ ${ }^{2}$ Department of Geology and Geophysics, University of Hawaii, Honolulu, HI 96822, USA \\ ${ }^{3}$ NOAA/Pacific Marine Environmental Laboratory, 7600 Sand Point Way NE, Seattle, WA 98115-0070, USA \\ ${ }^{4}$ NOAA/Pacific Marine Environmental Laboratory, Hatfield Marine Science Center, Newport, OR 97365, USA
}

(Received July 29, 1994; accepted in revised form July 8, 1995)

\begin{abstract}
In November, 1991, we surveyed the water column for hydrothermal plumes along $350 \mathrm{~km}$ of the East Pacific Rise axis from $8^{\circ} 40^{\prime}$ to $11^{\circ} 50^{\prime} \mathrm{N}$, using a combination of physical and chemical measurements. Our survey included the two major ridge segments north and south of the Clipperton Transform Fault at about $10^{\circ} 10^{\prime} \mathrm{N}$, both limbs of the overlapping spreading centers (OSC's) at $9^{\circ} 03^{\prime} \mathrm{N}$ and $11^{\circ} 45^{\prime} \mathrm{N}$, and a $30-\mathrm{km}$ section of the next ridge segment to the south. We found vigorous plumes along most of this ridge axis, in keeping with its magmatically robust cross-section, axial summit caldera, and shallow, magma-related seismic reflector. These plumes were detectable by both physical (temperature and light attenuation) and chemical (dissolved $\mathrm{Mn}$ and $\mathrm{CH}_{4}$ ) measurements, although the chemical measurements were more sensitive. The least active sections were the southern third of the northern segment from $10^{\circ} 20$ to $52^{\prime} \mathrm{N}$ and the OSCs, especially the OSC at $11^{\circ} 45^{\prime} \mathrm{N}$. Plumes there had weak $\mathrm{Mn}$ and $\mathrm{CH}_{4}$ signals and were barely detectable by physical methods. These axial sections were the only ones surveyed that lie deeper than $2600 \mathrm{~m}$ and appear to be magma starved. The most active sections on the northern segment gave stronger signals for $\mathrm{Mn}$ and temperature than for $\mathrm{CH}_{4}$ and light attenuation, whereas the opposite was true on the southern segment, which was the site of a volcanic eruption at $9^{\circ} 45-52^{\prime} \mathrm{N}$ only seven months prior to our cruise. On the northern segment the four physical and chemical plume tracers correlated positively and linearly with one another, suggesting that the segment was fed by relatively uniform endmember fluids with a mean $\mathrm{CH}_{4} / \mathrm{Mn}$ molar ratio of 0.075 . The southernmost section surveyed, from $8^{\circ} 42^{\prime}$ to $9^{\circ} 08^{\prime} \mathrm{N}$, closely resembled the northern segment. The rest of the southern segment fell into three sections with different $\mathrm{CH}_{4} / \mathrm{Mn}$ ratios: $9^{\circ} 39$ to $53^{\prime} \mathrm{N}$ with $\mathrm{CH}_{4} / \mathrm{Mn}$ as high as $10,9^{\circ} 08$ to $39^{\prime} \mathrm{N}$ with $\mathrm{CH}_{4} / \mathrm{Mn}$ of 0.51 , and $9^{\circ} 53^{\prime}$ to $10^{\circ} 07^{\prime} \mathrm{N}$ with $\mathrm{CH}_{4} / \mathrm{Mn}$ of 0.85 . The section with the highest $\mathrm{CH}_{4} / \mathrm{Mn}$ was the sile of the volcanic eruption, which produced high-temperature, low-salinity, gas-rich vent fluids carrying abundant bacterial particles. The high $\mathrm{CH}_{4}$ concentrations are clearly associated with the volcanic eruption, but the origin of the $\mathrm{CH}_{4}$ is unclear.
\end{abstract}

\section{INTRODUCTION}

Formation of oceanic crust along the global mid-ocean ridge system is typically accompanied by hydrothermal circulation of seawater through the newly formed crust. The resulting heat loss and chemical exchange are large and have an important effect on crustal structure and composition. Evaluating this effect as a function of spreading rate requires detailed knowledge of the distribution and intensity of hydrothermal venting in space and time along the mid-ocean ridge axis. Seafloor vents are small features that are difficult to detect, but they give rise to plumes of warm water that mix with ocean bottomwater and rise buoyantly through the water column. Because these plumes reach density equilibrium and spread laterally, they can integrate the output from a large number of individual vents. The hydrothermal plumes represent a larger target than the vents themselves and they are detectable both physically and chemically. For these reasons, detecting and measuring these plumes is the most efficient way to determine the distribution and relative intensity of hydrothermal venting along the mid-ocean ridge axis. The plumes also carry information about the physical and chemical characteristics of the hydrothermal systems that feed them.
On the TROUGHS (Tropical Ridge Observations of Underwater Geochemical Hydrothermal Signals) cruise in November, 1991, we surveyed the water column along $350 \mathrm{~km}$ of the East Pacific Rise (EPR) axis using a combination of physical and chemical measurements that were applied to both hydrocasts (thirty-seven, including three background casts) and tow-yos (fourteen along axis and four across, along a total track length of $540 \mathrm{~km}$ ). The survey required only 18 days and covered two major ridge segments, a southern segment from the overlapping spreading center (OSC) at $9^{\circ} 03^{\prime} \mathrm{N}$ to the Clipperton Transform Fault (CTF) at $10^{\circ} 10^{\prime} \mathrm{N}$, and a northern segment from the CTF at $10^{\circ} 18^{\prime} \mathrm{N}$ to the OSC at $11^{\circ} 45^{\prime} \mathrm{N}$ (Fig. 1). We also surveyed both limbs of both OSC's and a short section of the next segment south, to $8^{\circ} 42^{\prime} \mathrm{N}$.

Preliminary results of the survey, including data on temperature, light attenuation, ${ }^{3} \mathrm{He}$, methane, manganese, and aluminum, were reported by Lupton et al. (1993). Details of the physical measurements and analysis of suspended particles werc given by Baker et al. (1994) and Feely et al. (1994), respectively. Here we present shipboard analyses for dissolved $\mathrm{Mn}$ and $\mathrm{CH}_{4}$ and compare 


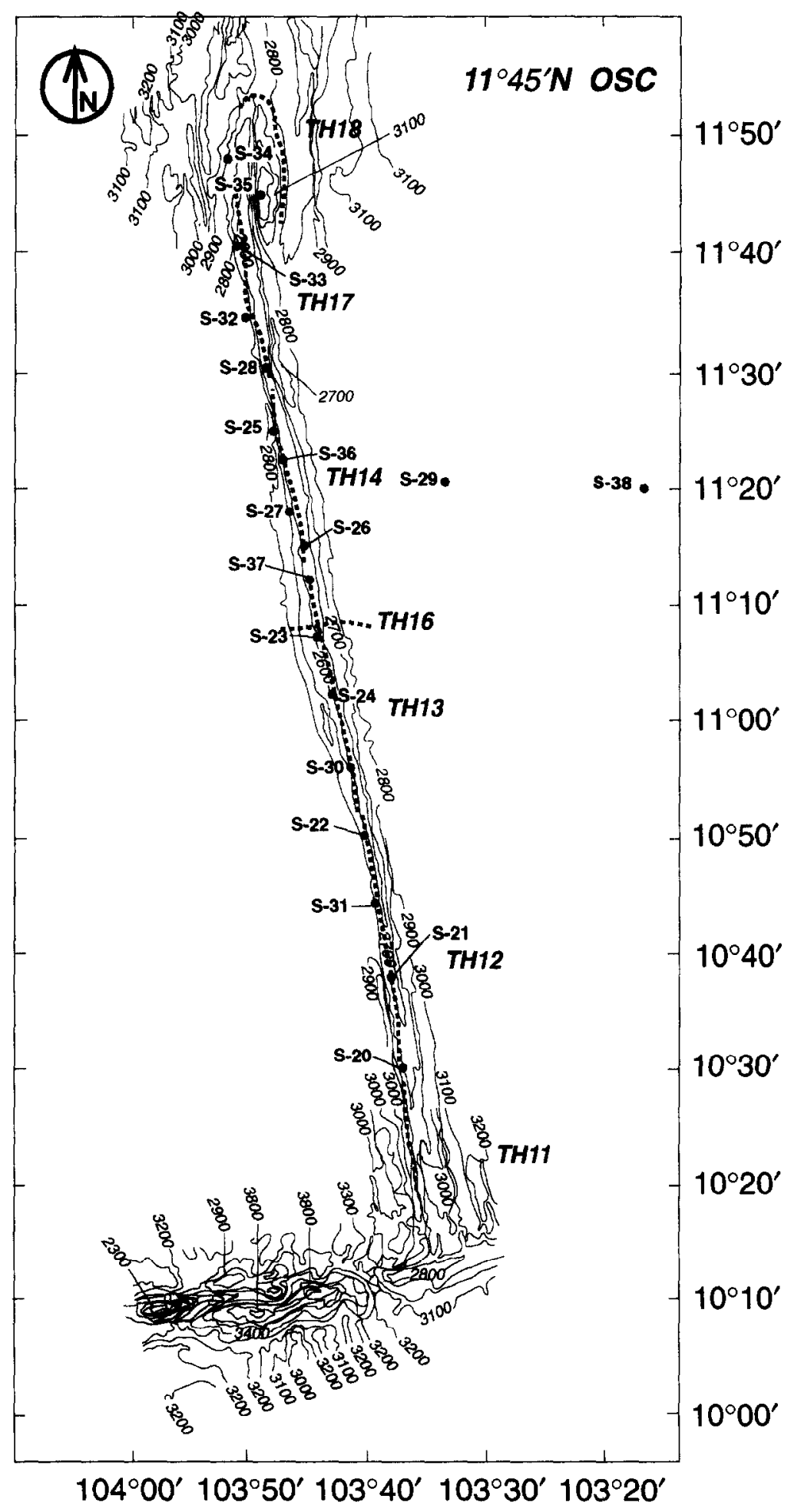

Fic. 1. Bathymetry and location of hydrocast stations (S) and tow-yo tracks (TH) along the East Pacific Rise north and south of the Clipperton Transform Fault. Not shown is off-axis station S-19 at $9^{\circ} 58.03^{\prime} \mathrm{N}, 103^{\circ} 49.3^{\prime} \mathrm{W}$.

them with results from the physical measurements. We then interpret these results in terms of the variation in geologic and hydrothermal processes along these ridge segments. Finally, we discuss the origin of the elevated $\mathrm{CH}_{4}$ and the diverse $\mathrm{CH}_{4} / \mathrm{Mn}$ ratios we observed in these plumes.

\section{GEOLOGIC SETTING}

The ridge segments north and south of the CTF have much in common, but some parts contrast sharply in their geologic characteristics, probably as a result of differing magma supply. Both segments shoal to $<2540 \mathrm{~m}$ north of their center and deepen toward their ends, especially as the CTF is approached (Fig. 1). Along much of their length they have a summit caldera, a robust cross-section, 


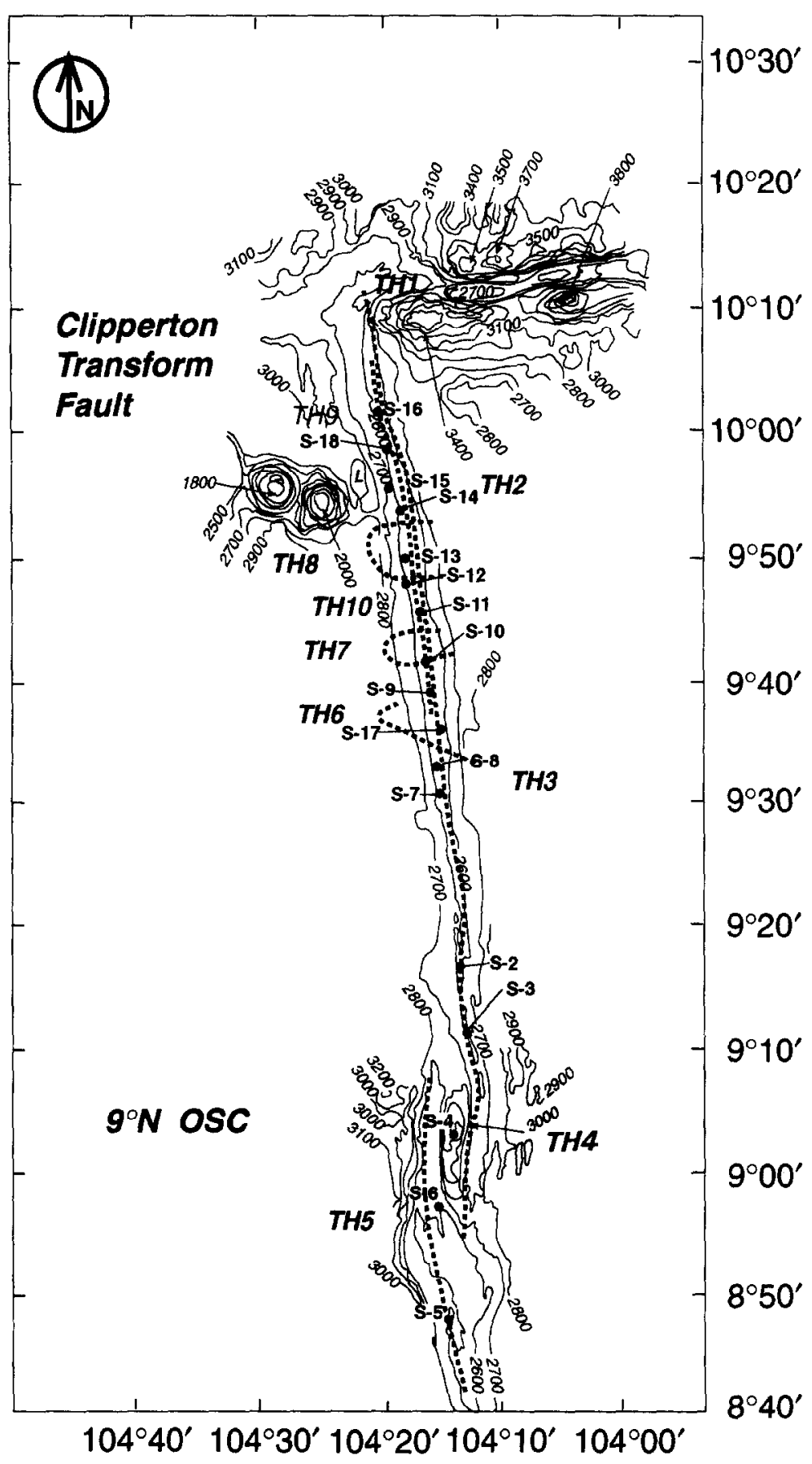

Fig. 1. (Continued)

and a seismic reflector $1.2-2 \mathrm{~km}$ below the seafloor interpreted as the top of an axial magma body (Macdonald and Fox, 1988). Although the southern segment has a rectangular cross-section and the northern segment is mainly domed, their cross-sectional areas are similar near their bathymetric highs (Scheirer and Macdonald, 1993).

The major exceptions to these generalizations are the OSC's and the southern third of the northern segment, from the CTF to about $10^{\circ} 50^{\prime} \mathrm{N}$. These sections are relatively deep: they are the only parts surveyed that, except for the western limb of the $11^{\circ} 45^{\prime} \mathrm{N}$ OSC, are uniformly below $2600 \mathrm{~m}$ at their crest. The southern third of the northern segment, the western limb of the $11^{\circ} 45^{\prime} \mathrm{N} \mathrm{OSC}$, and the eastern limb of the $9^{\circ} 03^{\prime} \mathrm{N}$ OSC are also the only sections that have a triangular, uninflated cross-section and lack a summit caldera and a magma reflector (Macdonald and Fox, 1988). All of these features suggest that these sections are magma starved. By contrast, the other limbs of the OSC's, which are continuous with the next ridge segments to the north and south rather than with those in the survey area, appear to be magmatically robust (Macdonald et al., 1984).

Hydrothermal venting has been visually observed on the segment north of the CTF, including on the eastern limb of the $11^{\circ} 45^{\prime} \mathrm{N}$ OSC (Ballard et al., 1984, 1988; McConachy et al., 1986; Fig. 2), and on the segment south of the CTF (Kastens et al., 1986; Haymon et al., 1991; Fig. 3). A camera survey of the $9^{\circ} 03^{\prime} \mathrm{N}$ OSC found no hydrothermal activity (Sempere and Macdonald, 1986). Part of the southern segment between $9^{\circ} 45^{\prime}$ and $9^{\circ} 52^{\prime} \mathrm{N}$ was the site of a volcanic eruption in April, 1991, the immediate results of which were witnessed from the manned submersible Alvin (Haymon et al., 1993). 

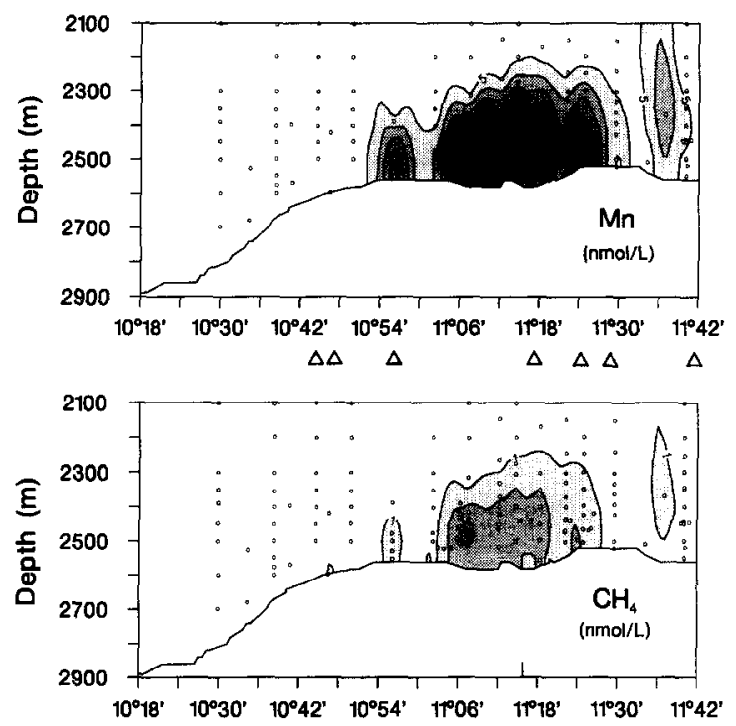

FIG. 2. Dissolved manganese and methane in the water column above the East Pacific Rise between the Clipperton Transform Fault at $10^{\circ} 18^{\prime} \mathrm{N}$ and the OSC at $11^{\circ} 45^{\prime} \mathrm{N}$. Contour interval is $5 \mathrm{nM}$ for manganese and $1 \mathrm{nM}$ for methane. Circles show locations of hydrocast and tow-yo samples. Triangles show locations of active hydrothermal vents discovered to date (Ballard et al., 1984, 1988; McConachy et al., 1986).

Our cruise followed this event by seven months, and some of our results clearly reflect the effects of this eruption.

\section{METHODS}

The same instrument/sampling package was used for both vertical hydrocasts and tow-yos. In the tow-yo mode, the package is towed in a sawtooth pattern by hauling it up and down as the ship moves forward at $2-3 \mathrm{~km} / \mathrm{h}$, usually between about 10 and $500 \mathrm{~m}$ above the seafloor and with a wavelength of $0.5-1 \mathrm{~km}$ (Baker et al., 1994). Tow-yos lasted from 8 to $20 \mathrm{~h}$ and averaged $14 \mathrm{~h}$. Watcr samples were taken where measurements of temperature and especially light attenuation indicated the presence of a plume. Most samples were taken either on the axis or about $1 \mathrm{~km}$ to the west, as we found from cross-axis tow-yos that bottom currents were carrying the plumes westward (Baker et al., 1994). Samples were collected on the upcast for the hydrocasts, which took 3-4 h altogether, and throughout the $8-20 \mathrm{~h}$ of the tow-yos. The tow-yo samples yielded similar results to the hydrocast samples, indicating that little $\mathrm{CH}_{4}$ or $\mathrm{Mn}$ was lost during the extra hours required to recover the tow-yo samples.

The equipment package consisted of a high-precision Sea Bird CTD, a $0.25 \mathrm{~m}$-path-length Sea Tech beam transmissometer, and a 12-bottle rosette fitted with an assortment of 10-, 12-, and 30-L Niskin ${ }^{\mathrm{TM}}$ bottles internally coated with Teflon and fitted with either silastic tubing or Tellon-coated springs for closure and silicon o-rings for sealing. Immediately on recovery, both unfiltered and filtered $(0.4$ $\mu \mathrm{m}$ Nucleopore ${ }^{\mathrm{TM}}$ polycarbonate) aliquots were taken from the bottles for various analyses onboard ship and ashore. Unfiltered, unacidified aliquots were taken for shipboard determination of $\mathrm{CH}_{4}, \mathrm{H}_{2}$, aluminum, and, on selected samples, $\mathrm{pH}$, alkalinity, and $\mathrm{O}_{2}$; and for shorebased determination of helium isotopes and salinity. An unfiltered aliquot was acidified for shorebased determination of total dissolvable $\mathrm{Mn}$. Fe, and other trace metals (C. G. Wheat and J. A. Resing, unpubl. data). Filtered unacidified aliquots were taken for shipboard determination of dissolved $\mathrm{Mn}$ and shorebased determination of nutrients, and for particle studies (Feely et al., 1994). One filtered aliquot was acidified for shorebased determination of dissolved trace metals.

Dissolved Mn(II) analyses presented here were performed on board ship on filtered, unacidified aliquots, generally within $12 \mathrm{~h}$ of recovery, using flow-injection analysis with on-line preconcentration and spectrophotometric detection (Resing and Mottl, 1992). The method has a detection limit of $0.036 \mathrm{nM}$ and a precision of $\pm 5 \%$ or better at a concentration ten times the detection limit. To check for contamination during filtration, we also analyzed unfiltered, unacidified aliquots of selected samples representing the full range of concentrations encountered. Concentrations in the unfiltered aliquots generally exceeded those in the filtered aliquots by $1-6 \%$. These results are consistent with the concentrations of particulate Mn measured by Feely et al. (1994) in the same sample suite; they found maximum concentrations in the plumes of $<3 \mathrm{nM}$, compared with maxima in dissolved $\mathrm{Mn}$ from the filtered aliquots of $76 \mathrm{nM}$ on the northern segment and $42 \mathrm{nM}$ on the southern segment.

Methane was determined onboard ship by helium stripping, followed by cold-trapping with liquid nitrogen and gas chromatography on a Varian $3300( \pm 1 \%)$ (Brooks et al., 1981). Samples were stored in 120 -mL glass bottles, preserved with $1.0 \mathrm{~mL}$ of saturated $\mathrm{HgCl}_{2}$ solution, and analyzed within $48 \mathrm{~h}$ of recovery. The bottles were filled to the brim and sealed with glass stoppers coated with Apiezon- $\mathrm{N}$ grease. Aliquots of $80 \mathrm{~mL}$ from the bottom of each bottle were transferred to the stipper by pressurized helium, care being taken to ensure that the water analyzed was not exposed to the atmosphere.

\section{RESULTS AND DISCUSSION}

Plumes of hydrothermal $\mathrm{Mn}$ and $\mathrm{CH}_{4}$ were detected along most of the surveyed ridge axis and in general correlate well with anomalies in temperature and light attenuation. On the northern segment, $\mathrm{Mn}$ gave a stronger signal than did $\mathrm{CH}_{4}$ (Fig. 2), whereas the opposite was true on the southern segment (Fig. 3). This pattern is similar to that for the physical measurements: the temperature anomaly, detected as a deviation from the background temperature-salinity relationship, was stronger on the northern segment whereas light attenuation was stronger on the southern segment (Lupton et al., 1993; Baker et al., 1994). In general, $\mathrm{Mn}$ and $\mathrm{CH}_{4}$ proved more sensitive than temperature and light attenuation for detecting plumes, including some originating from known vents that were barely detectable by the physical measurements.

Except for three background casts, all our hydrocasts and tow-yos were done on or near the ridge axis in order to sample near-zero-age nonbouyant plumes. The plumes sampled should have been young enough to retain nearly all of their original content of dissolved $\mathrm{Mn}$ and $\mathrm{CH}_{4}$, based on measurements of removal rates from nonbuoyant hydrothermal plumes at the Juan de Fuca Ridge axis, at concentrations similar to those encountered here. Scavenging times for dissolved $\mathrm{Mn}$ are typically a few months to a few years, as measured using ${ }^{54} \mathrm{Mn}$ (Cowen et al., 1990; Lavelle et al., 1992; Mandernack and Tebo, 1993). Methane residence times with respect to oxidation are a few days to a few weeks, as measured using ${ }^{14} \mathrm{C}$ ( De Angelis et al., 1993) and the ${ }^{222} \mathrm{Rn} /{ }^{3} \mathrm{He}$ 'clock' (Kadko et al., 1990). As noted above, the particles recovered from our samples contain very low concentrations of hydrothermal Mn (Feely et al., 1994). The relative concentrations of dissolved $\mathrm{Mn}$ and $\mathrm{CH}_{4}$ measured in our samples of EPR hydrothermal plumes should therefore reflect mainly the composition of the source vents and dilution by ambient seawater.

Of the three "background" hydrocasts (Fig. 1), only S19 , located at $9^{\circ} 58^{\prime} \mathrm{N} 67 \mathrm{~km}$ east of the axis on the southern segment, gave credible background values for dissolved $\mathrm{Mn}$ $(0.14 \pm 0.07 \mathrm{nM})$ and $\mathrm{CH}_{4}(0.11 \pm 0.06 \mathrm{nM})$. The two casts on the northern segment, located at $11^{\circ} 20^{\prime} \mathrm{N} 28 \mathrm{~km}$ (S-29) and $56 \mathrm{~km}(\mathrm{~S}-38)$ east of the axis, provided puzzling results. Cast S-29 showed Mn increasing to $4 \mathrm{nM}$ and $\mathrm{CH}_{4}$ to $0.4 \mathrm{nM}$ 

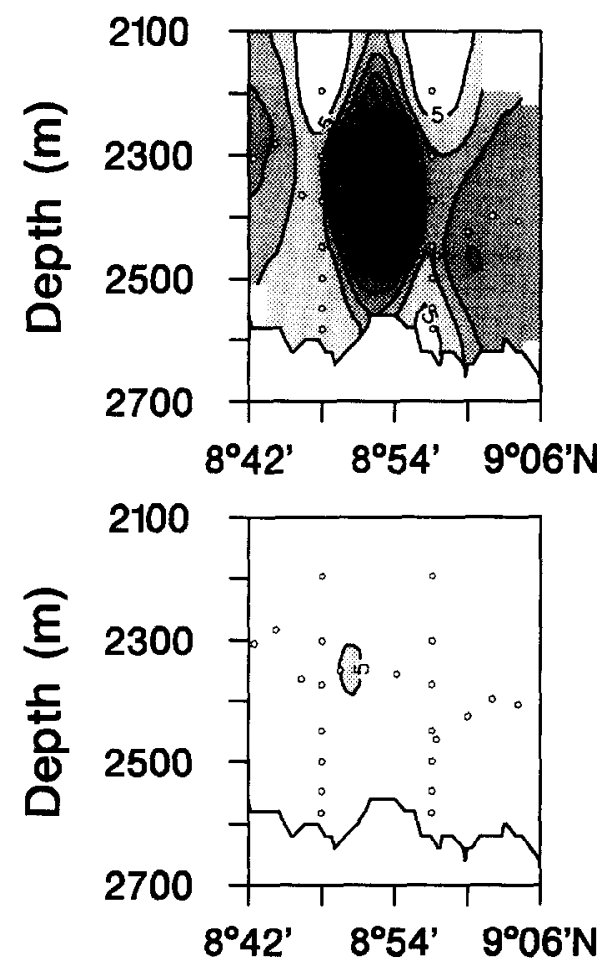
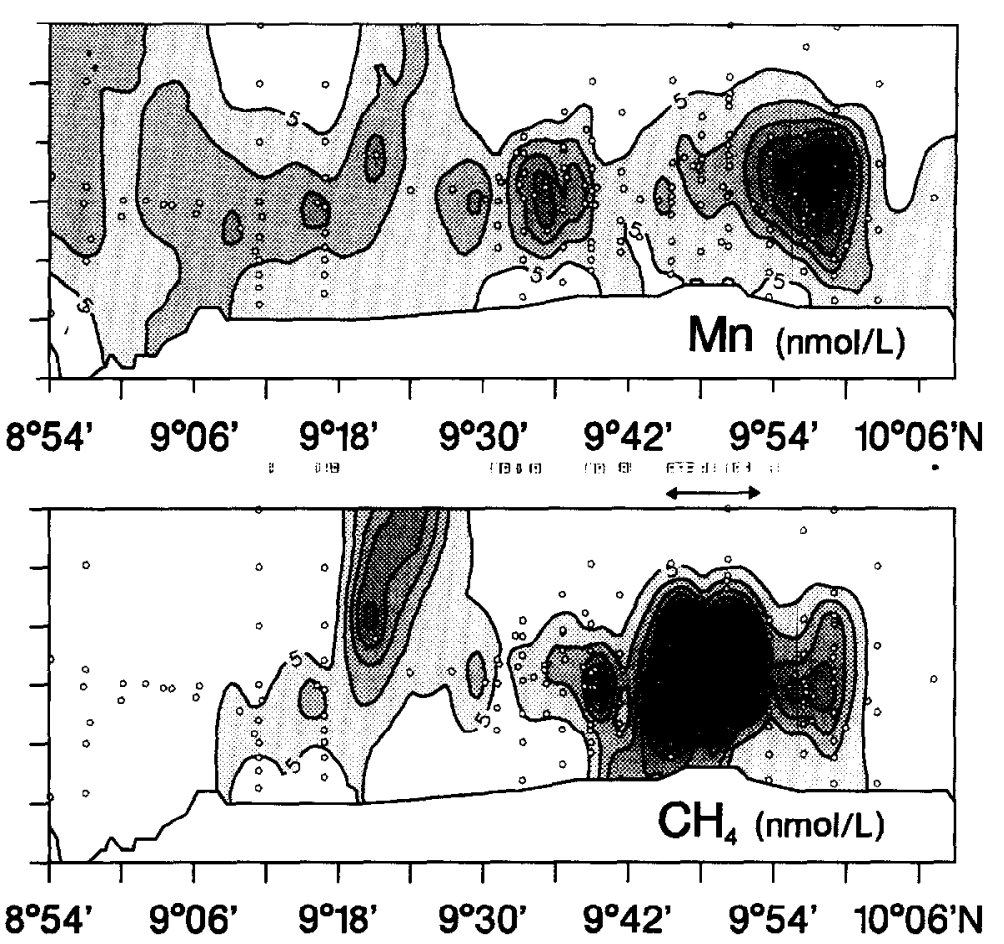

FIG. 3. Dissolved manganese and methane in the water column above the East Pacific Rise between the OSC at $9^{\circ} 03^{\prime} \mathrm{N}$ and the Clipperton Transform Fault at $10^{\circ} 10^{\prime} \mathrm{N}$. The diagram on the right shows the eastern limb of the OSC; that on the left shows the western limb of the OSC and the northem end of the next segment south, from $8^{\circ} 56^{\prime} \mathrm{N}$ to $8^{\circ} 42^{\prime} \mathrm{N}$. Contour interval is $5 \mathrm{nM}$ for both manganese and methane. Solid boxes are sites of active high-temperature venting as determined by Haymon et al. (1991); the included dots mark black smokers. Dashed boxes indicate cloudy fluid that may result from lower temperature venting. The double-headed arrow denotes the extent of the 1991 volcanic eruption (Haymon et al., 1993).

from $2300 \mathrm{~m}$ to the bottom at $2951 \mathrm{~m}$. Cast S-38, though further east, showed even higher $\mathrm{Mn}$ and $\mathrm{CH}_{4}$, this time increasing from $2100 \mathrm{~m}$ to the bottom at $3004 \mathrm{~m}$ but with distinct maxima at $2600 \mathrm{~m}$ depth. Maximum concentrations were $7 \mathrm{nM} \mathrm{Mn}$ and $0.8 \mathrm{nM} \mathrm{CH}_{4}$; concentrations at the seafloor were $5 \mathrm{nM} \mathrm{Mn}$ and $0.4 \mathrm{nM} \mathrm{CH}_{4}$. Given the westward drift of the axial plumes seen in cross-axis tows on both the northern and southern segments (Baker et al., 1994), these elevated values suggest an additional hydrothermal source, probably a seamount on the ridge flank to the east of the northern segment. Alternatively, the bottom currents may have shifted with time from eastward to westward.

\subsection{Distribution of Plumes along the Northern Segment}

On the northern segment plumes were most intense between $10^{\circ} 52^{\prime}$ and $11^{\circ} 30^{\prime} \mathrm{N}$, where the ridge axis is uniformly shallower than $2600 \mathrm{~m}$ (Fig. 2). Three devals have been identified along this section, at $11^{\circ} 08^{\prime} \mathrm{N}$ (near the highest $\mathrm{Mn}$ measured; Fig. 2), $11^{\circ} 19^{\prime} \mathrm{N}$, and $11^{\circ} 29^{\prime} \mathrm{N}$ (Macdonald and Fox, 1988). All nine hydrocasts in this region showed maxima in dissolved $\mathrm{Mn}$ of 9-76 nM and $\mathrm{CH}_{4}$ of $1.0-5.9 \mathrm{nM}$ at depths from 70-290 $\mathrm{m}$ above the seafloor (Fig. 4b). A tenth hydrocast (S-32) at $11^{\circ} 34^{\prime} \mathrm{N}$ showed peaks of $12 \mathrm{nM} \mathrm{Mn}$ (Fig. 5a) and $1.4 \mathrm{nM} \mathrm{CH}_{4}$ at $254 \mathrm{~m}$ above the seafloor. The $\mathrm{CH}_{4}$ profiles closely followed those for Mn. Besides showing maxima well above the seafloor, $\mathrm{Mn}$ and $\mathrm{CH}_{4}$ persisted at relatively high concentrations (3-34 nM Mn, 0.4-2.5 nM $\mathrm{CH}_{4}$ ) to within about $20 \mathrm{~m}$ of the bottom (Fig. 4; note that most of the contours in Fig. 2 intersect the seafloor). This low-lying hydrothermal cloud may have resulted from diffuse venting at lower temperatures, which would rise much less than focused venting via high-temperature black smokers (Rona and Speer, 1989; Rona and Trivett, 1992). In addition, a few of the hydrocasts ( $\mathrm{S}-23$ (= Cast 36 in Lupton et al., $1993,-37,-25,-34)$ showed distinct double peaks which probably resulted from mixing of hydrothermal solutions from multiple vent sources.

Hydrothermal venting appeared to be less intense as the seafloor deepens toward the CTF to the south and the $11^{\circ} 45^{\prime} \mathrm{N}$ OSC to the north. The correlation between a shallower ridge crest and greater hydrothermal activity is not perfect, however, as activity lessened to the north even though the ridge axis is entirely above $2600 \mathrm{~m}$ from $10^{\circ} 48^{\prime}$ to $11^{\circ} 46^{\prime} \mathrm{N}$. Three of four hydrocasts from $10^{\circ} 30$ to $50^{\prime} \mathrm{N}$ showed only a basal cloud of hydrothermal $\mathrm{Mn}$ and $\mathrm{CH}_{4}$, accompanied by a slight increase in light attenuation, that was much weaker $(<2 \mathrm{nM}$ $\mathrm{Mn}$ ) than that to the north; only hydrocast S-31 at $10^{\circ} 44^{\prime} \mathrm{N}$ showed small but distinct maxima ( $7 \mathrm{nM} \mathrm{Mn}$ ) higher in the water column (Fig. 4a). While these hydrothermal signals could have been transported laterally to the positions where we sampled them, the general westward drift of the plumes seen in cross-axis tows (Baker et al., 1994) suggests that they probably were generated locally by weak venting that was 
(a)

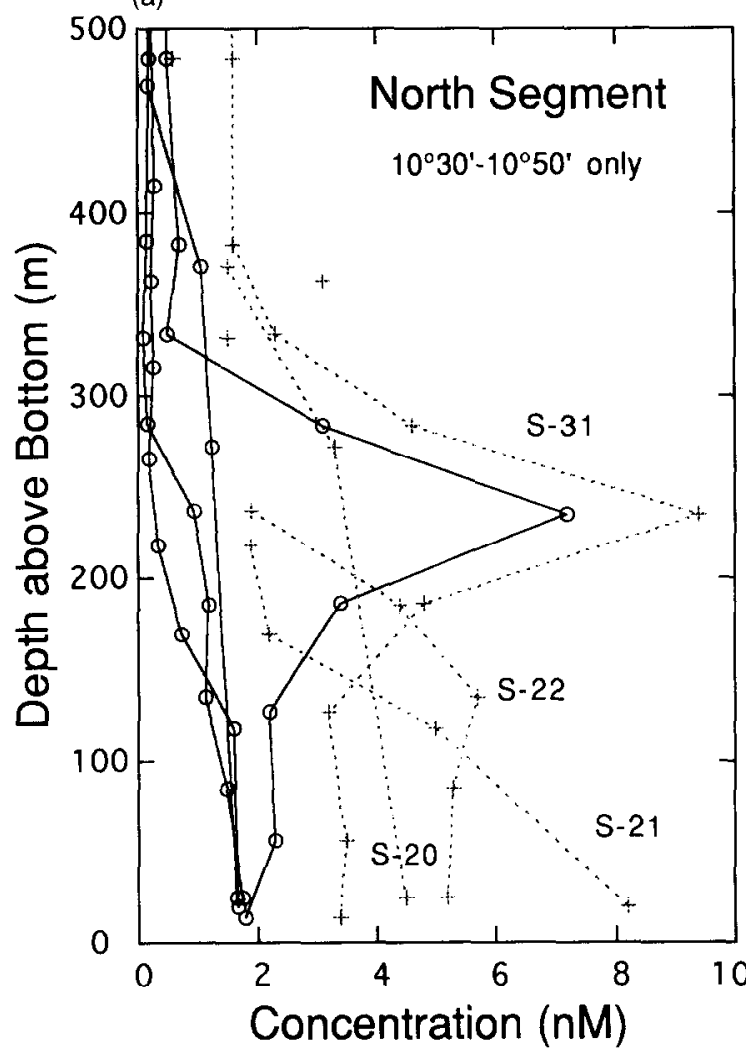

(b)

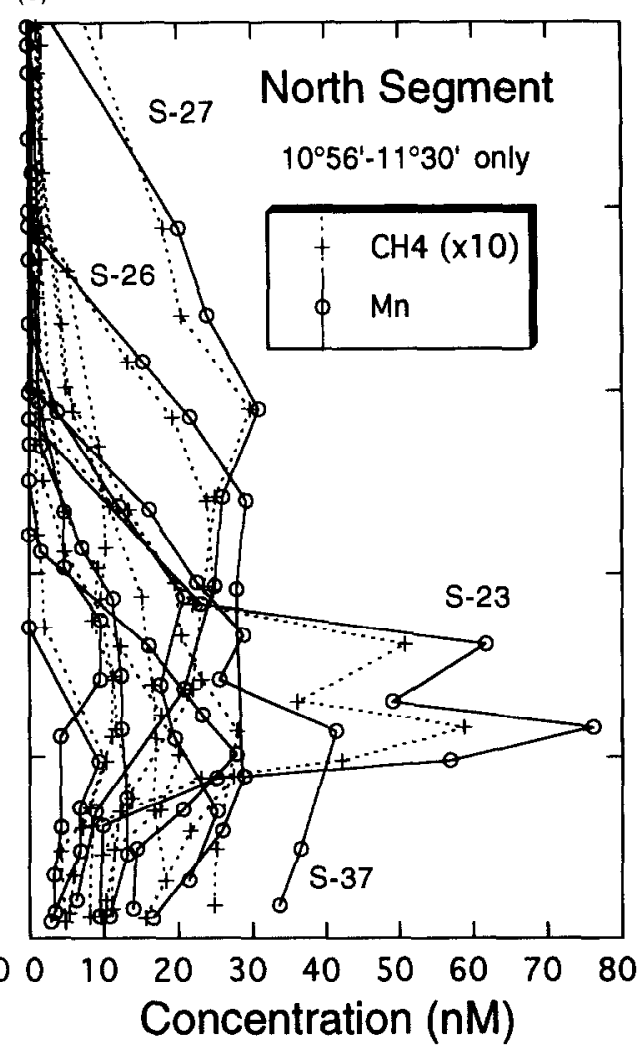

FiG. 4. Dissolved manganese and methane in the water column above the East Pacific Rise from (a) $10^{\circ} 30^{\prime}$ to $50^{\prime} \mathrm{N}$ and (b) $10^{\circ} 56^{\prime}$ to $11^{\circ} 30^{\prime} \mathrm{N}$, as sampled by hydrocasts.

both diffuse and, near $10^{\circ} 44^{\prime} \mathrm{N}$, focused. Indeed, active vents have been observed at $10^{\circ} 44$ to $47^{\prime} \mathrm{N}$ by the ARGO vehicle, but they appeared to be Galapagos-style warm springs rather than hot springs (Ballard et al., 1988).

The OSC at $11^{\circ} 45^{\prime} \mathrm{N}$ likewise showed signs of weak but probably focused venting (Fig. 5a). Tow-yo TH18 on the eastern limb of the OSC, which is believed to be magmatically robust, yielded $\mathrm{Mn}$ and $\mathrm{CH}_{4}$ concentrations as high as $\mathbf{8}$ and $1.1 \mathrm{nM}$, respectively, consistent with the presence of vents there as observed by Ballard et al. (1988). Two hydrocasts (S-33, S-34) on the western limb, which is believed to be magma starved, also showed distinct plumes, with Mn and $\mathrm{CH}_{4}$ up to 5 and $0.7 \mathrm{nM}$, respectively, and accompanying anomalies in temperature and light attenuation (Baker et al., 1994). There is some ambiguity in the magmatic characteristics of this OSC, however. While the eastern limb is broad and has a domed cross-section, an axial summit caldera, and a shallow magma reflector, it is deep ( $>2750 \mathrm{~m}$ ). By contrast, the western limb is narrow and triangular and lacks a summit caldera and magma reflector, but it is relatively shallow $(<2600 \mathrm{~m}$ ) (Macdonald et al., 1984; Macdonald and Fox, 1988). A hydrocast (S-35) in the nodal basin, which lies between the two limbs of the OSC and exceeds $3160 \mathrm{~m}$ in depth, showed a hydrothermal plume maximum (4.4 nM Mn, 0.6 $\mathrm{nM} \mathrm{CH}$ ) at the same water depth as those on the limbs, indicating that the plume almost certainly originated elsewhere and was carried over the basin by currents. Nonetheless, elevated concentrations of $\mathrm{Mn}(1.3 \mathrm{nM})$ and $\mathrm{CH}_{4}(0.6 \mathrm{nM})$ persisted to the lowermost sample in the basin at $3143 \mathrm{~m}$. Their origin is unknown.

\subsection{Distribution of Plumes Along the Southern Segment}

Hydrothermal plumes were nearly ubiquitous on the southern segment, which has devals at $9^{\circ} 17^{\prime} \mathrm{N}$ and $9^{\circ} 53^{\prime} \mathrm{N}$. Thirteen of fourteen hydrocasts between $9^{\circ} 12^{\prime}$ and $10^{\circ} 03^{\prime} \mathrm{N}$ showed maxima in $\mathrm{Mn}$ and $\mathrm{CH}_{4}$ in the water column from 20 to $310 \mathrm{~m}$ above the seafloor; only hydrocast S-16 at $10^{\circ} 03^{\prime} \mathrm{N}$ lacked a peak and showed instead a basal enrichment ( $6 \mathrm{nM}$ each of $\mathrm{Mn}$ and $\mathrm{CH}_{4}$ ) (Fig. 6). The basal enrichments in $\mathrm{Mn}$ that characterized the northern segment were largely lacking on the southern segment, where concentrations near the seafloor were generally low ( $1-5 \mathrm{nM})$. This suggests that diffuse venting of low-temperature solutions rich in Mn was less common on the southern than the northern segment. Although basal $\mathrm{CH}_{4}$ concentrations can be quite high $(1-10 \mathrm{nM})$, most of the contours in Fig. 3 are closed and do not intersect the seafloor, in contrast with Fig. 2. As on the northern segment, several of the plumes (S-7, -8, -9, -11 ( = Cast 18 in Lupton et al., 1993, -15, -18) showed distinct double peaks which probably resulted from mixing of hydrothermal solutions from multiple vent sources.

On the southern segment the $\mathrm{Mn}$ and $\mathrm{CH}_{4}$ plumes were largely decoupled. The $\mathrm{CH}_{4}$ plumes were most intense from $9^{\circ} 39$ to $53^{\prime} \mathrm{N}$, reaching $80 \mathrm{nM}$, whereas the Mn plumes were most intense immediately to the south and north, at about $9^{\circ} 32$ 

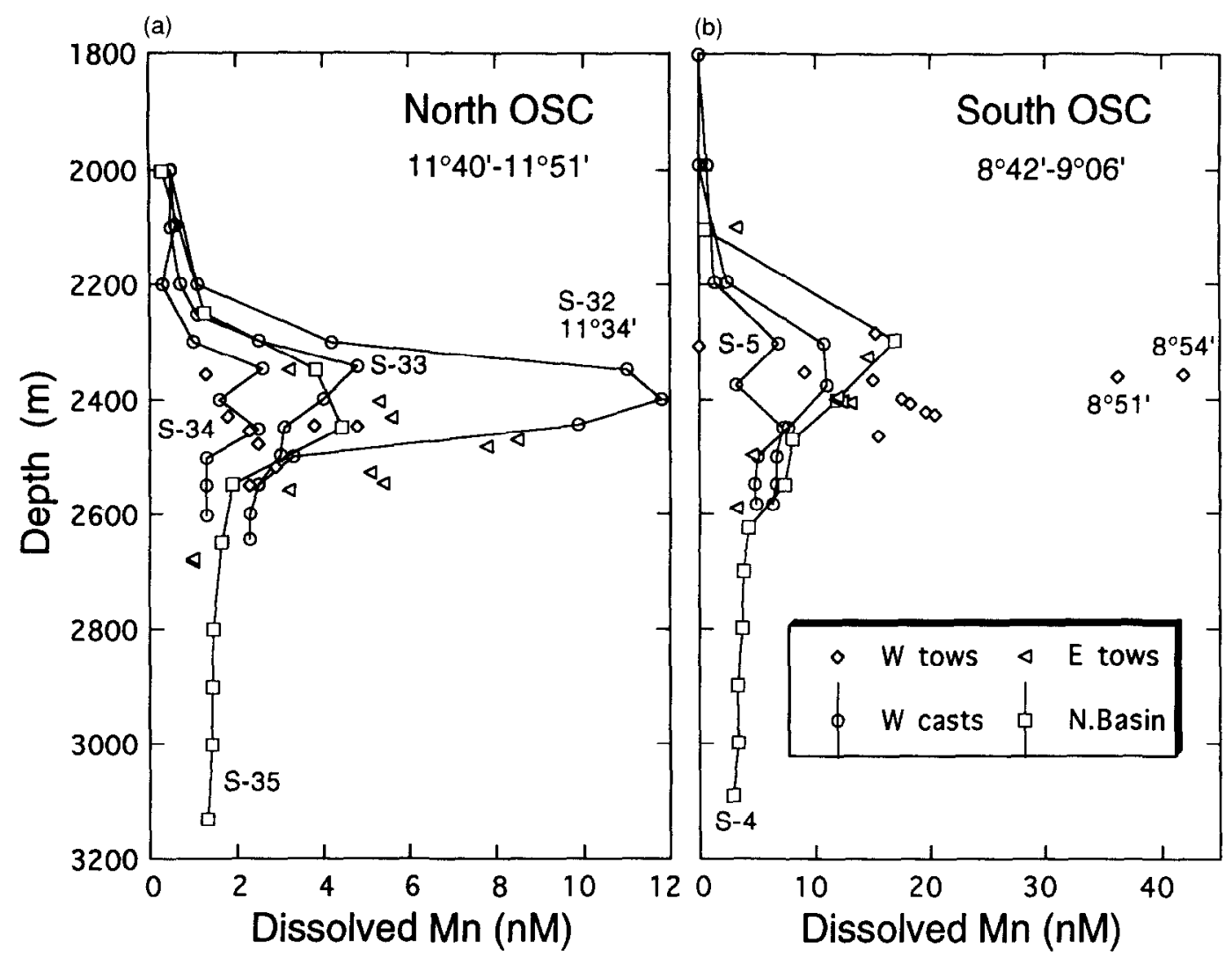

FIG. 5. Dissolved manganese in the water column above (a) the $11^{\circ} 45^{\prime} \mathrm{N}$ OSC and (b) the $9^{\circ} 03^{\prime} \mathrm{N}$ OSC, as sampled by hydrocasts and tow-yos. Also shown for comparison in (a) is a hydrocast from the axis at $11^{\circ} 34^{\prime} \mathrm{N}$.
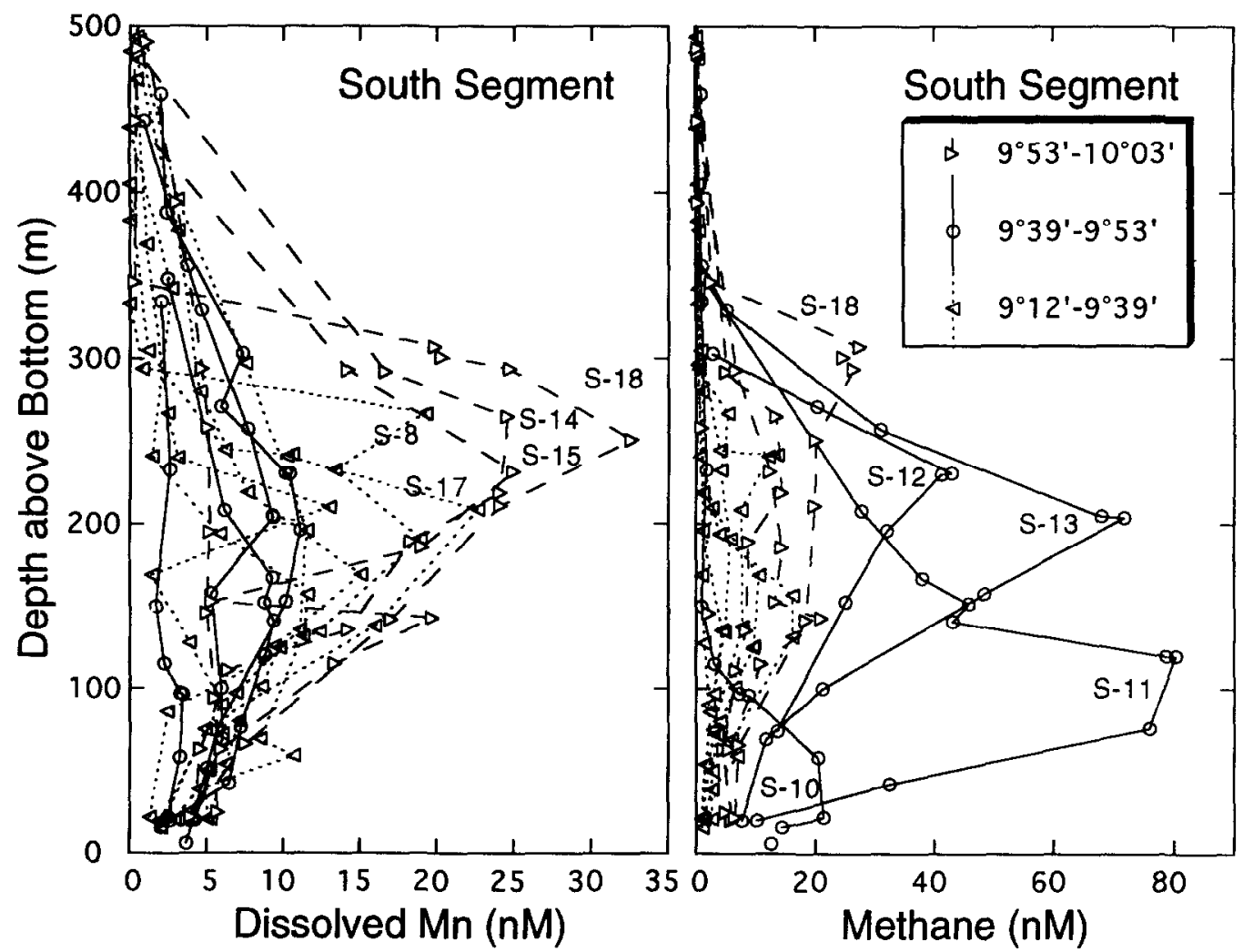

FiG. 6. Dissolved manganese and methane in the water column above the East Pacific Rise from $9^{\circ} 12^{\prime}$ to $10^{\circ} 03^{\prime} \mathrm{N}$, as sampled by hydrocasts. 
to $39^{\prime} \mathrm{N}$ and $9^{\circ} 53^{\prime}$ to $10^{\circ} 02^{\prime} \mathrm{N}$ (Figs. 3,7 ). From $9^{\circ} 39$ to $53^{\prime} \mathrm{N}$, where the $\mathrm{CH}_{4}$ plumes were most intense, $\mathrm{Mn}$ was uniformly $<19$ and generally $<12 \mathrm{nM}$, whereas $\mathrm{Mn}$ reached
30 and $37 \mathrm{nM}$ just to the south and north, respectively. Figure 7 shows that, except for the OSC at $9^{\circ} 03^{\prime} \mathrm{N}, \mathrm{CH}_{4}$ was much higher on the southern segment than the northern. By contrast,
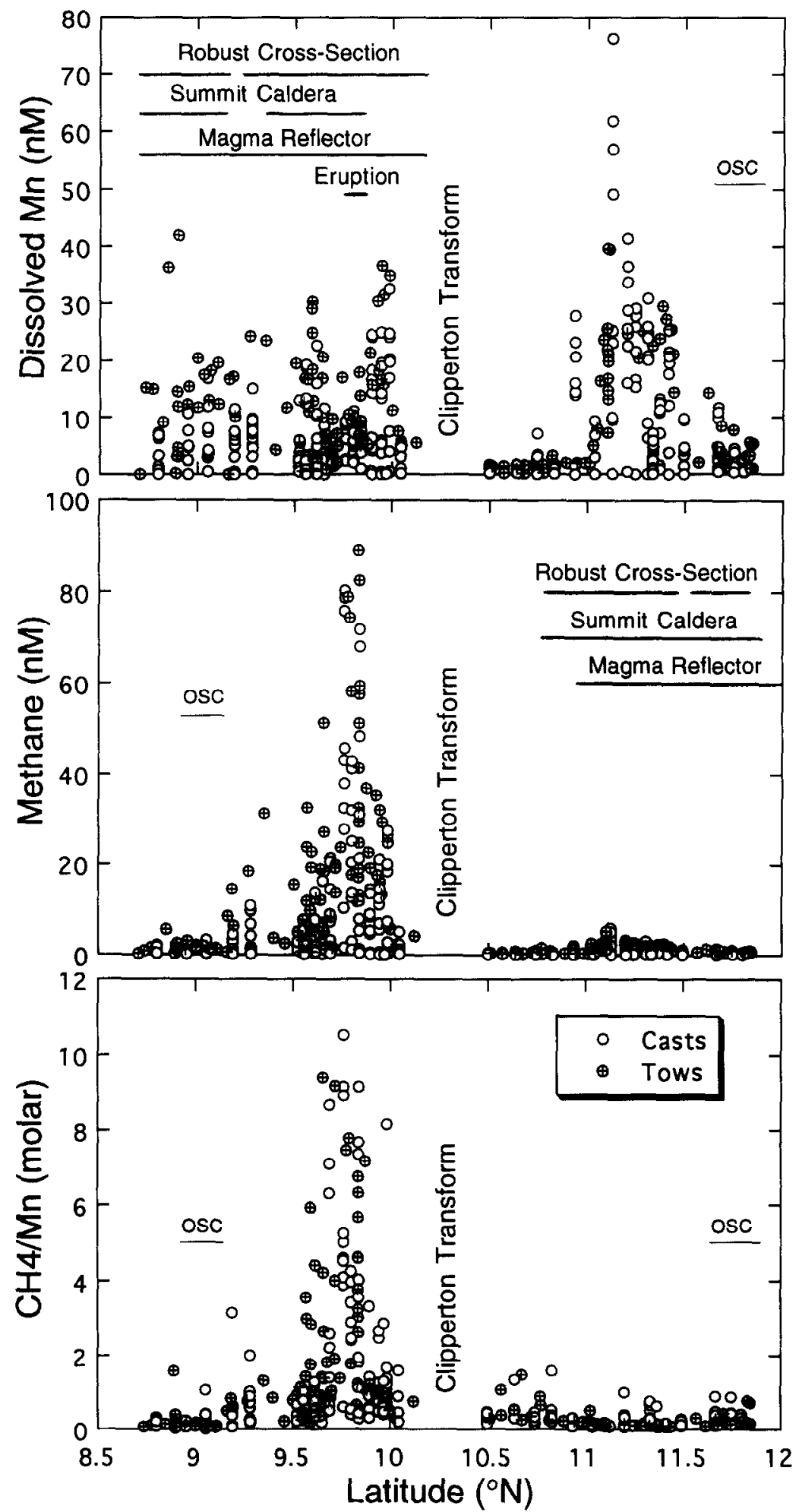

Fic. 7. Concentrations of dissolved manganese and methane and the $\mathrm{CH}_{4} / \mathrm{Mn}$ ratio in the water column above segments of the East Pacific Rise north and south of the Clipperton Transform Fault, as sampled by hydrocasts and tow-yos. Geologic and geophysical characteristics vs. latitude, including the site of the 1991 volcanic eruption, are from Detrick et al. (1987), Macdonald and Fox (1988), and Haymon et al. (1991, 1993). 
Mn was similar on the two segments, including on the OSCs; only the deep section of the northern segment from $10^{\circ} 30$ to $52^{\prime} \mathrm{N}$, which has a triangular cross-section and lacks a summit caldera and a magma reflector, had significantly lower $\mathrm{Mn}$. The most $\mathrm{CH}_{4}$-rich plumes varied widely in their rise height, setting the extremes for the dataset at 20 and $310 \mathrm{~m}$ (Fig. 6). The plume with the highest $\mathrm{CH}_{4}$ measured ( $80 \mathrm{nM}$ ) rose only $120 \mathrm{~m}$. In general, the plumes on the southern segment rose higher than did those on the northern segment (Fig. 8; compare also Figs. 4 and 6). Manganese and $\mathrm{CH}_{4}$ peaked at 200 $m$ or more above the seafloor in nine of fourteen hydrocasts on the southern segment, but in only five of fifteen casts on the northern segment.

The region of high $\mathrm{CH}_{4}$ and $\mathrm{CH}_{4} / \mathrm{Mn}$ ratio corresponds almost exactly with the site of the volcanic cruption at $9^{\circ} 45$ to $52^{\prime} \mathrm{N}$ in April, 1991, seven months prior to our cruise. Fluids vented from this site in 1991 through holes, cracks, and pits in new lava flows and rubble rather than through sulfide chimneys, which had not yet formed (Haymon et al., 1993). The fluids were highly unusual: they had the lowest salinities yet recorded from a seafloor vent (as low as $33 \mathrm{mmol} / \mathrm{kg}$ chlorinity; Von Damm et al., 1995) and were very rich in dissolved gases, including $\mathrm{H}_{2} \mathrm{~S}$ as high as $110 \mathrm{mmol} / \mathrm{kg}$ (Von Damm et al., 1995) and $\mathrm{CH}_{4}$. Low-temperature diffuse vents had the highest $\mathrm{CH}_{4}$ concentrations, up to $300 \mu \mathrm{M}$, while high-temperature vents had concentrations of 10 to $115 \mu \mathrm{M}$ (Lilley et al., 1991, 1992). The fluids are believed to form by subcritical phase separation about $200 \mathrm{~m}$ below the seafloor. Some of the vents at the eruption site, called 'snowblowers,' were also emitting thick clouds of white bacterial particles which contributed to a bacterial 'blizzard' in the lowermost several tens of meters of the water column. These bacteria are believed to grow on a basaltic substrate in open spaces within the seafloor, and to be forcefully ejected by vigorous hydrothermal flow resulting from the eruption (Haymon et al., 1993). Submersible dives one year later, in March 1992, showed that this activity had subsided considerably (Haymon et al., 1992), while salinities had increased and gas contents decreased (Von Damm et al., 1995; Lilley et al., 1992).

The unusual composition of the low-salinity fluids probably accounts for the decoupling of $\mathrm{Mn}$ from $\mathrm{CH}_{4}$ along the southern segment: fluids away from the eruption site have more normal gas contents and salinity, and hence higher Mn concentrations, than would the low-salinity fluids. In a study of similar fluids produced by subcritical phase separation on Axial Seamount on the Juan de Fuca Ridge, Massoth et al. (1989) and Butterfield et al. (1990) found that the low-salinity, gas-rich vents had a much lower Mn concentration ( 162 $\mu \mathrm{mol} / \mathrm{kg}$ ) than did the vents with higher salinity and lower gas concentrations $(1133 \mu \mathrm{mol} / \mathrm{kg}$ ). The low-salinity fluids at Axial Seamount, like those at $9^{\circ} 45$ to $52^{\prime} \mathrm{N}$, vented from bare basalt rather than through sulfide mounds or chimneys, at both low and high temperatures, and by both diffuse and focused flow. This unusual mode of venting probably accounts for the great variation in rise height of the most $\mathrm{CH}_{4}$ rich plumes at the $9^{\circ} 45$ to $52^{\prime} \mathrm{N}$ eruption site.

The OSC at $9^{\circ} 03^{\prime} \mathrm{N}$, like that at $11^{\circ} 45^{\prime} \mathrm{N}$, showed hydrothermal plumes over both limbs and the nodal basin

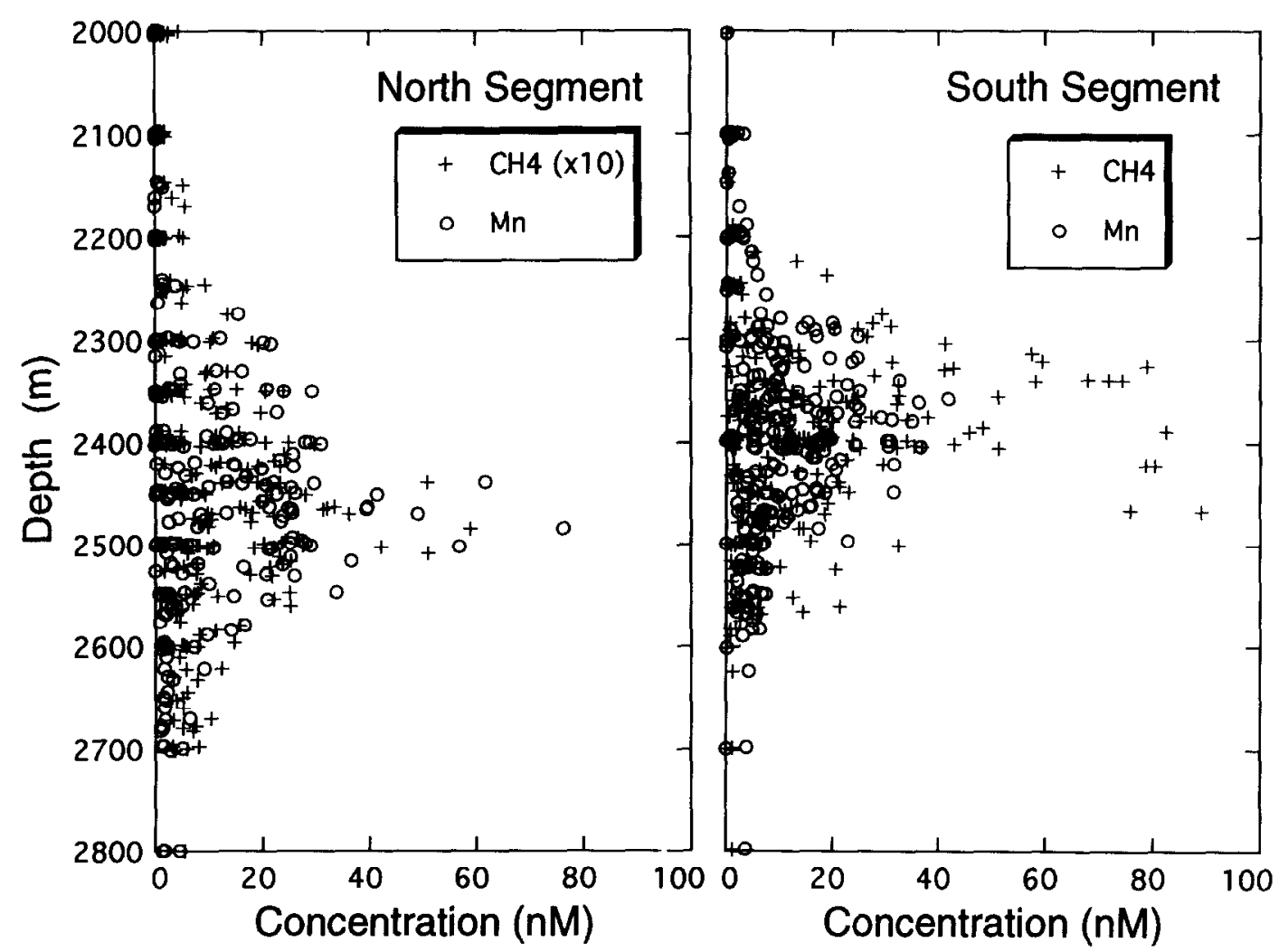

FiG. 8. Dissolved manganese and methane in the water column above the East Pacific Rise from $8^{\circ} 42^{\prime}$ to $11^{\circ} 51^{\prime} \mathrm{N}$, as sampled by hydrocasts and tow-yos. 

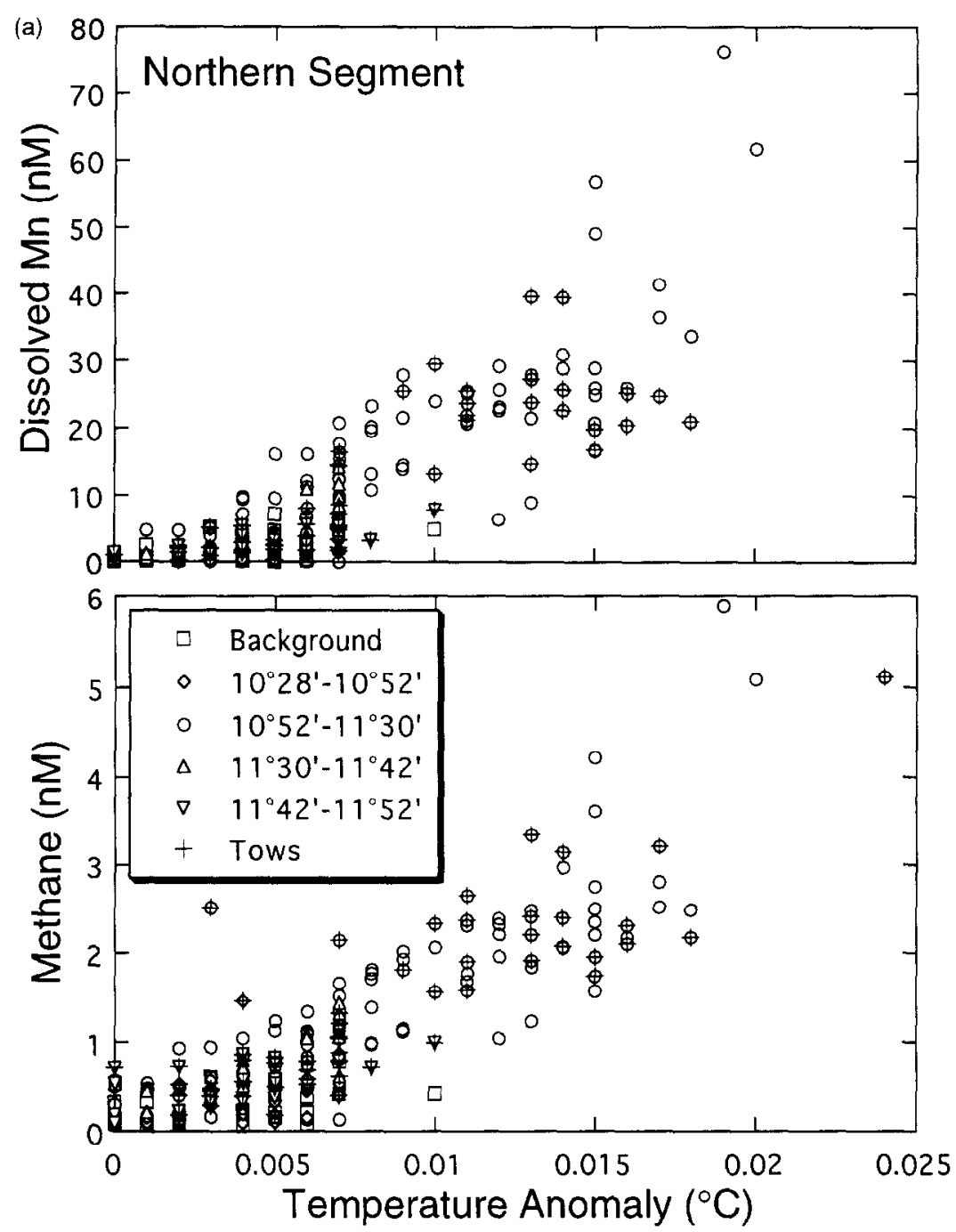

FIG. 9. Concentrations of dissolved manganese and methane in the water column above the segment of the East Pacific Rise north of the Clipperton Transform Fault, plotted against the temperature anomaly relative to ambient water of the same potential density and the light attenuation anomaly, as measured by transmissometry.

(Fig. 5b). The western limb, which by all evidence is magmatically robust, appeared to be more active than the eastern limb, which appears to be magma starved. Data coverage of the eastern limb consisted of only four towyo samples, but these all showed a hydrothermal signal (12-13 nM Mn, 1.2-2.0 $\mathrm{nM} \mathrm{CH}_{4}$ ), as did the light attenuation measurements (Baker et al., 1994). This signal could have been carried in laterally, but it is more likely to be of local origin, given the evidence from cross-axis tows for westward-flowing bottom currents (Baker et al., 1994 ). Flow along the axis is equally unlikely, given the sharp lateral gradients in $\mathrm{Mn}$ and $\mathrm{CH}_{4}$ with latitude (Fig. 7). The $\mathrm{Mn}$ and $\mathrm{CH}_{4}$ maxima over the nodal basin, however, certainly originated elsewhere and were carried in by currents, as they lie at the same water depth as the ridge-axis plumes. As was the case at the northern OSC, slightly elevated concentrations of $\mathrm{Mn}(3 \mathrm{nM})$ and $\mathrm{CH}_{4}$ $(1.0 \mathrm{nM})$ persisted to the seafloor at $3100 \mathrm{~m}$.

\subsection{Correlation with Other Plume Properties on the Northern Segment}

On the northern segment the chemical and physical parameters correlate well with one another and define a single trend (Figs. 9, 10a). The plots against temperature scatter more than the others hecause of uncertainty in calculating the temperature anomaly (Baker et al., 1994). The molar ratio of $\mathrm{CH}_{4}$ to $\mathrm{Mn}$ is 0.075 , compared with a nearly uniform value of 0.12 along the $13^{\circ} \mathrm{N}$ segment of the EPR (Charlou et al., 1991a). The simple relationship defined by the data, in which each parameter correlates positively and linearly with every other parameter measured, suggests that the high-temperature endmember solutions feeding the vents were relatively uniform in temperature and composition along the entire northern segment, and that the main process affecting the plume data was mixing between these endmembers and ambient bot- 

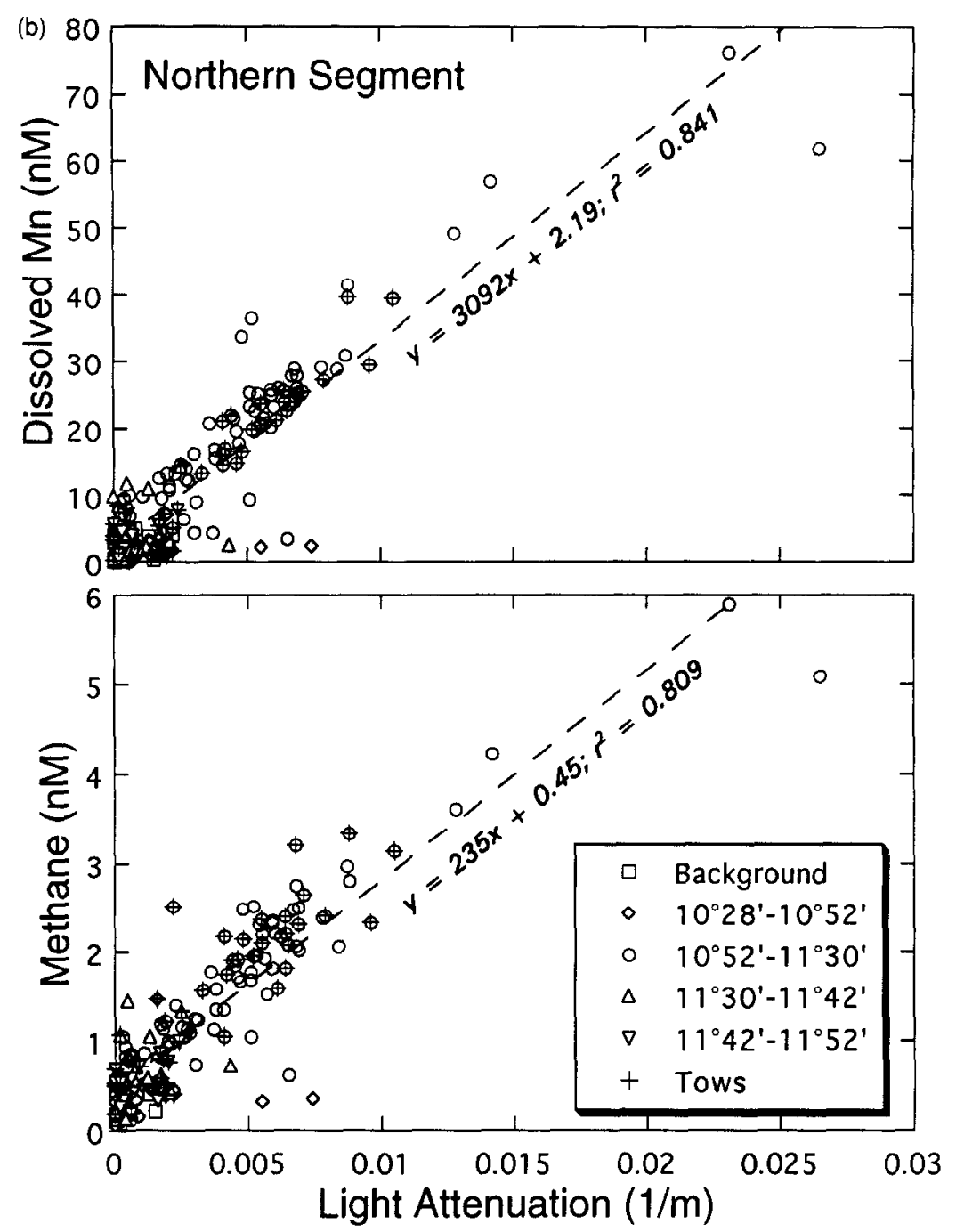

FIG. 9. (Continued)

tom seawater. Massoth et al. (1994), however, showed that considerable chemical variation in vent fluids both along axis and with time can be masked by homogenization within the plumes. They found that variations as high as fivefold in $\mathrm{Mn} /$ heat and $\mathrm{Fe} /$ heat between focused vents on the Juan de Fuca Ridge could not be detected in the overlying plumes. The relationships in Figs. 9 and 10a could therefore be explained by relatively uniform vent compositions along the northern segment, homogenization within the plumes, or a combination of the two.

The linear relationships also imply that all of the species shown here have behaved largely conservatively in these axial, near-zero-age plumes. This conclusion is consistent with the likely residence times of dissolved Mn (months to years) and $\mathrm{CH}_{4}$ (days to weeks), as discussed above. Particles filtered from the plumes on the northern segment were rich in $\mathrm{Fe}, \mathrm{S}$, and $\mathrm{Si}$, but not $\mathrm{Mn}$; particulate $\mathrm{Mn}$ increased toward the scafloor suggesting resuspension of bottom sediments (Feely et al., 1994).

Baker et al. (1994) showed that the light-attenuation anomaly correlates linearly with particle mass concentration along the northern segment (but not along the southern). That Mn and $\mathrm{CH}_{4}$ both correlate linearly with light attenuation does not require that either species be directly involved in particle formation, but only that both correlate with other species in the high-temperature endmember that did form particles, such as Fe, S, and Si (Feely et al., 1994). The same endmember with a relatively uniform high temperature and concentrations of $\mathrm{Fe}, \mathrm{S}, \mathrm{Si}, \mathrm{Mn}$, and $\mathrm{CH}_{4}$ probably supplied vents all along the segment. As this hot water mixed with ambient seawater, it precipitated $\mathrm{Fe}$ oxyhydroxides and sulfides but retained most of its $\mathrm{Mn}$ and $\mathrm{CH}_{4}$ prior to our sampling.

\subsection{Correlation with Other Plume Properties on the Southern Segment}

On the southern segment the relationships are much more complex. A plot of $\mathrm{Mn}$ vs. $\mathrm{CH}_{4}$ (Fig. 10b) defines three distinct groups that separate with latitude. The southernmost group, from $8^{\circ} 42^{\prime}$ to $9^{\circ} 08^{\prime} \mathrm{N}$ and including the southern OSC and part of the next ridge segment to the south, defines a trend that is indistinguishable from that for the northern segment, implying that the high-temperature endmember solution supplying this section of ridge is similar to that supplying the 

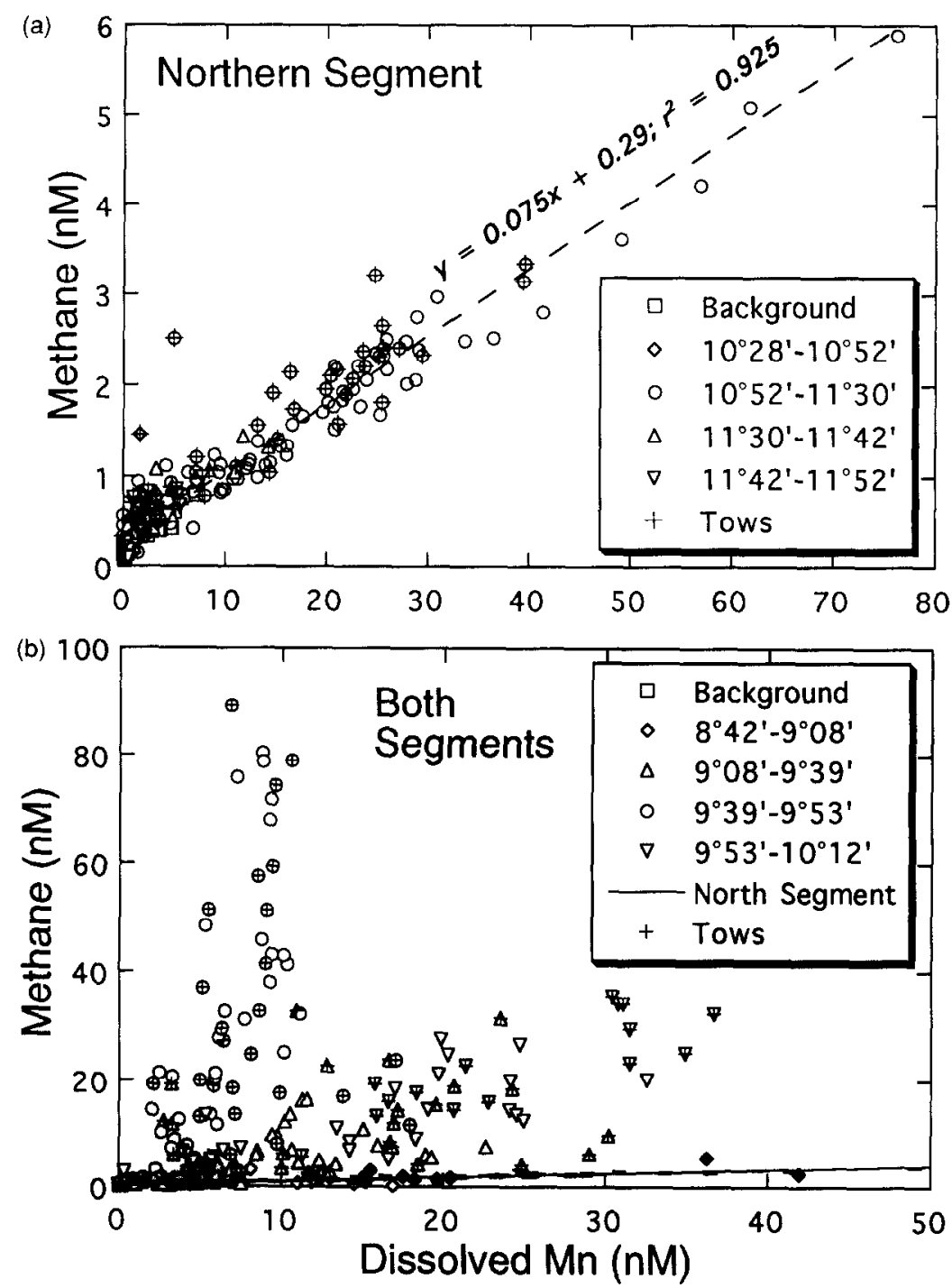

FiG. 10. Concentrations of dissolved manganese vs. methane in the water column above segments of the East Pacific Rise (a) north and (b) south of the Clipperton Transform Fault, as sampled by hydrocasts and tow-yos. Note the difference in scales between the upper and lower diagrams.

northern segment. This endmember is relatively $\mathrm{Mn}$ rich and $\mathrm{CH}_{4}$ poor, with a $\mathrm{CH}_{4} / \mathrm{Mn}$ molar ratio of about 0.069 . At the other extreme is the group from $9^{\circ} 39$ to $53^{\prime} \mathrm{N}$, the site of the volcanic eruption, which is $\mathrm{CH}_{4}$ rich and $\mathrm{Mn}$ poor and has $\mathrm{CH}_{4} / \mathrm{Mn}$ ratios as high as 10 . The third group has an intermediate $\mathrm{CH}_{4} / \mathrm{Mn}$ ratio. It originates immediately south and north of the eruption site: from $9^{\circ} 08$ to $39^{\prime} \mathrm{N}$ the $\mathrm{CH}_{4} / \mathrm{Mn}$ ratio is 0.51 with considerable scatter, and from $9^{\circ} 53^{\prime}$ to $10^{\circ} 07^{\prime} \mathrm{N}$ it is 0.85 with much less scatter.

Only the southernmost group from $8^{\circ} 42^{\prime}$ to $9^{\circ} 08^{\prime} \mathrm{N}$ (along with the northern segment) separates out in plots of the temperature anomaly vs. $\mathbf{M n}, \mathbf{C H}_{4}$, and light attenuation (Fig. 11). For most of the southern segment, from $9^{\circ} 08$ to $10^{\circ} 12^{\prime} \mathrm{N}$, $\mathrm{Mn}, \mathrm{CH}_{4}$, and light attenuation are not strongly dependent on the temperature anomaly. The Mn data scatter on both sides of the trend for the northern segment, with many samples from $9^{\circ} 08$ to $39^{\prime} \mathrm{N}$ and $9^{\circ} 53^{\prime}$ to $10^{\circ} 12^{\prime} \mathrm{N}$ showing more $\mathrm{Mn}$ for a given temperature anomaly than on the northern segment, and some from $8^{\circ} 42^{\prime}$ to $9^{\circ} 08^{\prime} \mathrm{N}$ showing less. The diversity of fluids venting on the southern segment, especially with respect to chloride and gas concentrations, probably accounts for the relative lack of temperature dependence, as discussed below. Charlou et al. (1991a) likewise found a lack of correlation between temperature and chemical hydrothermal tracers along the EPR between $11^{\circ} 40^{\prime}$ and $13^{\circ} \mathrm{N}$, which they attributed in part to variable vent fluid characteristics.

The three groups are again distinct when $\mathrm{Mn}$ is plotted against the light attenuation anomaly (Fig. 12a). This is an obvious result of the correlation between light attenuation and $\mathrm{CH}_{4}$ on the southern segment (Fig. 12b); both light attenuation and $\mathrm{CH}_{4}$ reveal the three groups when plotted against dissolved Mn. (Compare Figs. 10b and 12a). Although light attenuation correlates with $\mathrm{CH}_{4}$ on both the northern and southern segments, the reasons are quite different. In the north, light attenuation correlates not only with $\mathrm{CH}_{4}$ but also with $\mathrm{Mn}$, temperature, total particle mass concentration 

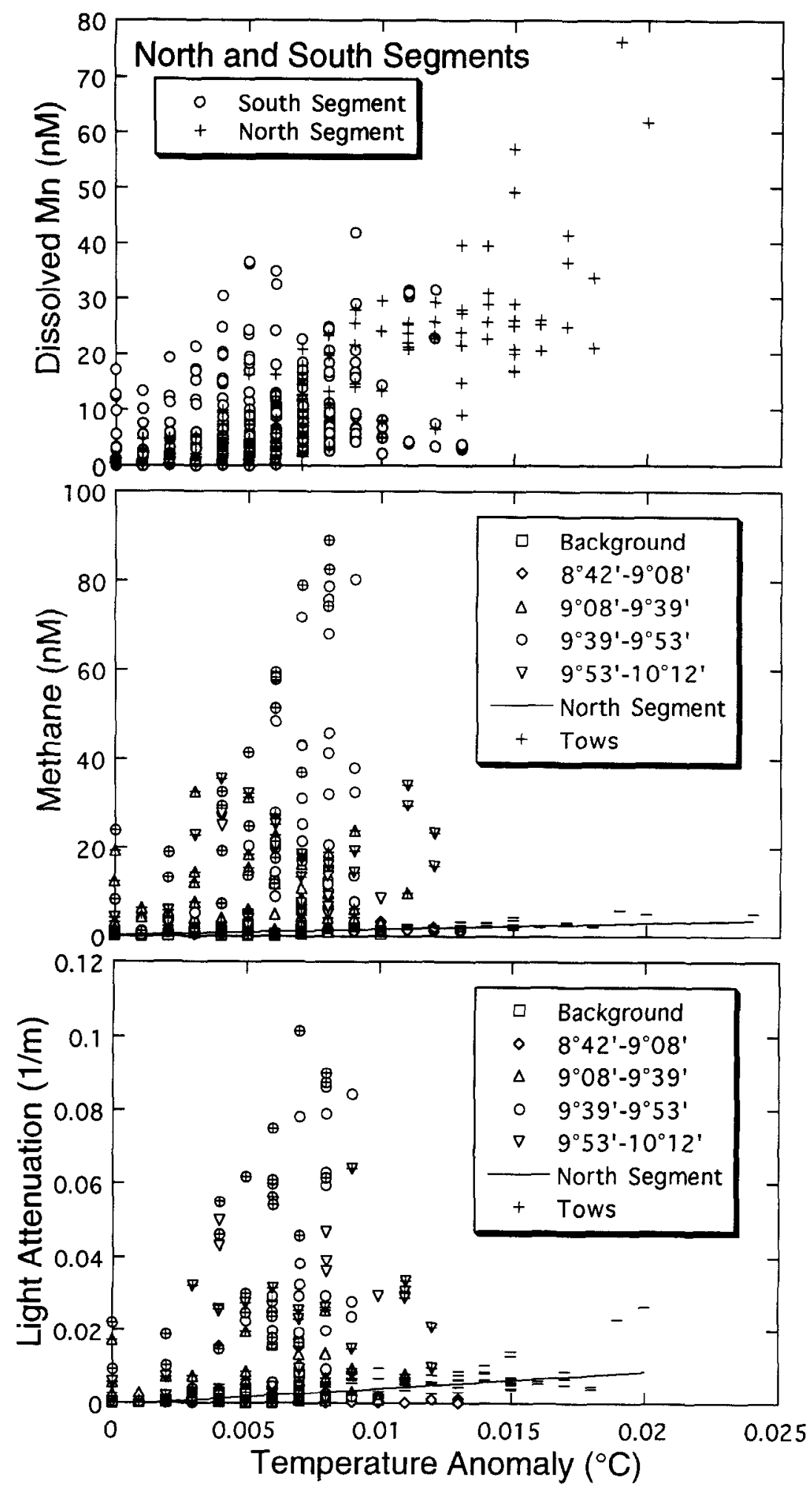

Fig. 11. Concentrations of dissolved manganese and methane and the light attenuation anomaly vs. temperature anomaly in the water column above segments of the East Pacific Rise north and south of the Clipperton Transform Fault, as sampled by hydrocasts and tow-yos.

(Baker et al., 1994), and particulate Fe, S, and Si (Feely et al., 1994). In the south, by contrast, light attenuation correlates only with $\mathrm{CH}_{4}$ and not with any of the other measured parameters, and $\mathrm{CH}_{4}$ is clcarly dccoupled from $\mathrm{Mn}$ and tem- perature. Why does light attenuation on the southern segment correlate with $\mathrm{CH}_{4}$ but not with particle mass concentration? The recent eruption at $9^{\circ} 45$ to $52^{\prime} \mathrm{N}$ and the accompanying subcritical phase separation (Von Damm et al., 1995; Hay- 

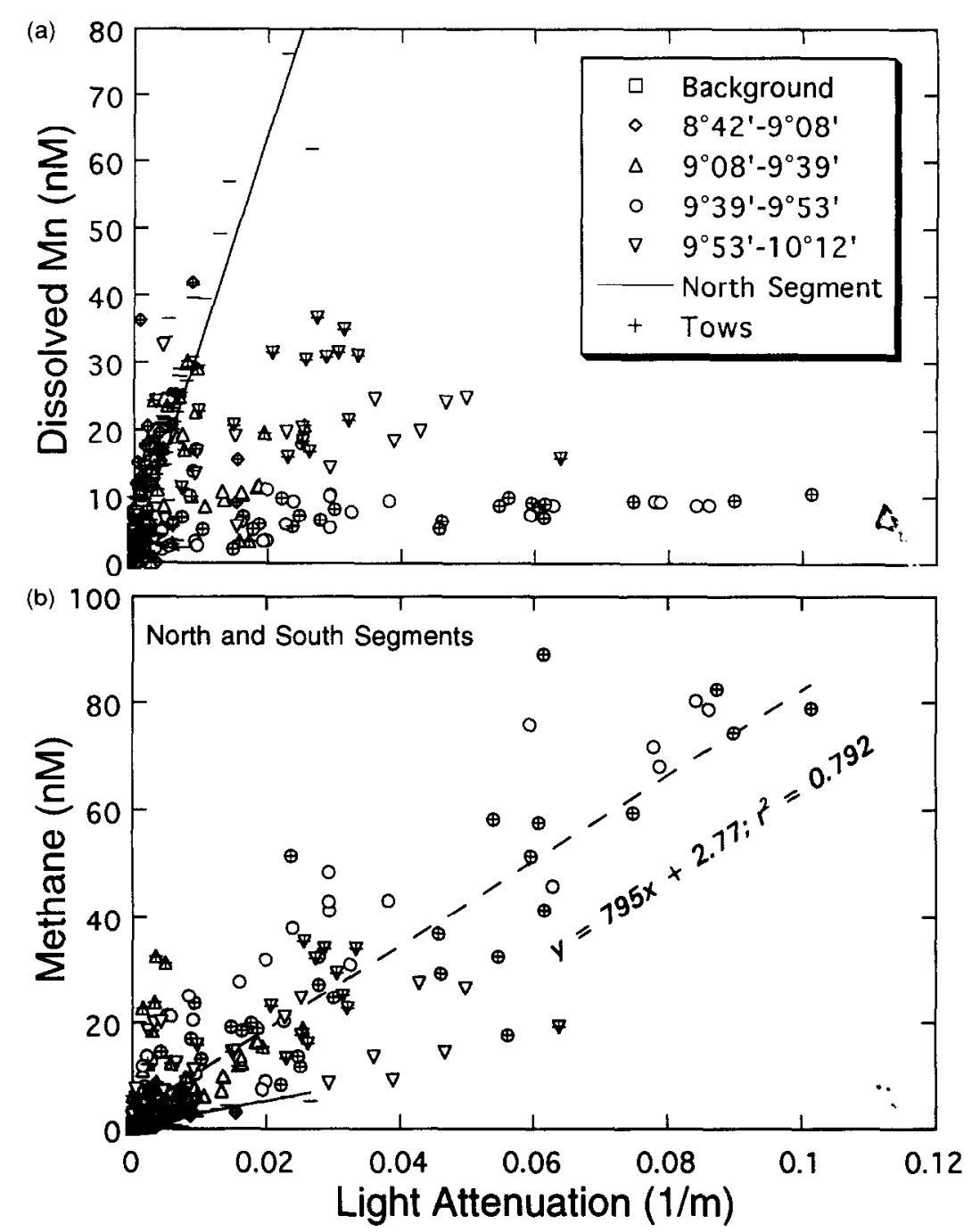

FIG. 12. Concentrations of (a) dissolved manganese and (b) methane vs. the light attenuation anomaly in the water column above segments of the East Pacific Rise north and south of the Clipperton Transform Fault, as sampled by hydrocasts and tow-yos. The solid lines are the regression lines for the northern segment from FiG. 9. The dashed line is for the southern segment.

mon et al., 1993) have produced extreme variations in chloride and gas concentrations in the fluids venting on this segment. Concentrations of $\mathrm{Mn}$ and other metals are likely to be higher in the separated brines, whereas $\mathrm{CH}_{4}$ will be higher in the vapor phase; both phases will be hot. These circumstances will effectively decouple $\mathrm{Mn}, \mathrm{CH}_{4}$, and temperature from one another in plumes that are formed from mixtures of several vent types. That $\mathrm{CH}_{4}$ remains related to light attenuation, which is in turn unrelated to particle mass concentration, points to the abundant particles of the bacterial blizzard, emitted in large part by the snowblower vents (Haymon et al., 1993), as the probable link between $\mathrm{CH}_{4}$ and light attenuation. These micrometer-sized, S-rich organic particles dominate by volume the particle population filtered from our samples (Feely et al., 1994). Whether the high $\mathrm{CH}_{4}$ concentrations are bacteriogenic, or whether the bacteria are abundant because they are feeding on biogenic and/or abiogenic $\mathrm{CH}_{4}$ and $\mathrm{H}_{2} \mathrm{~S}$ from the gas-rich, low-salinity vents, cannot be de- termined without carbon isotopic data on the $\mathrm{CH}_{4}$; these analyses are in progress on both the vent and the plume solutions.

\subsection{Variable $\mathrm{CH}_{4} / \mathrm{Mn}$ and Diverse Origins of $\mathrm{CH}_{4}$}

While nearly all hydrothermal vents on the seafloor contain elevated concentrations of $\mathrm{CH}_{1}$ relative to those in seawater, typically by a factor of $10^{5}-10^{7}$ (De Angelis et al., 1993), $\mathrm{CH}_{4}$ concentrations and the $\mathrm{CH}_{4} / \mathrm{Mn}$ ratio vary widely in these vents and for a variety of reasons. In a recent review, Welhan (1988) listed four main sources for $\mathrm{CH}_{4}$ in hydrothermal systems: (1) thermal breakdown of complex hydrocarbons at $>100^{\circ} \mathrm{C},(2)$ biological production, (3) outgassing of juvenile $\mathrm{CH}_{4}$, and (4) inorganic synthesis at $>300-400^{\circ} \mathrm{C}$. Thermal breakdown of complex hydrocarbons, typically derived from organic matter in sediments, has been documented on sedimented mid-ocean ridges such as in Guaymas Basin (Simoneit, 1983) and Middle Valley on the Juan de Fuca Ridge 
(Davis et al., 1993). It has also been invoked to explain high $\mathrm{CH}_{4}$ concentrations at an unsedimented ridge, the Endeavour segment of the Juan de Fuca Ridge (Lilley et al., 1993), and at an intracontinental back-arc spreading axis in the Okinawa Trough (Sakai et al., 1990; Gamo et al., 1991). Biological production by bacteria commonly occurs at Galapagos-type low-temperature vents (Lilley et al., 1983; Jannasch and Mottl, 1985), and it may occur at higher temperatures as well (Baross et al., 1982). Outgassing of juvenile $\mathrm{CH}_{4}$ is difficult to demonstrate, but high concentrations of $\mathrm{CH}_{4}$ are often associated with high ${ }^{3} \mathrm{He}$, which is almost certainly juvenile. ${ }^{3} \mathrm{He}$ and $\mathrm{CH}_{4}$ could be either outgassed directly from magma or leached from glassy basalt by circulating seawater and still qualify as juvenile in origin. Inorganic synthesis at high temperature can occur during reaction of seawater with either basalt or periodotite, both of which can produce sufficiently reducing conditions to generate $\mathrm{CH}_{4}$. Plumes rich in $\mathrm{CH}_{4}$ have been described that are associated with serpentinized ultramafic rocks along the Mid-Atlantic Ridge near $15^{\circ} \mathrm{N}$ and elsewhere (Charlou et al., 1991b; Charlou and Donval, 1993).

In Table 1, submarine hydrothermal vents and their associated plumes have been divided into three groups based on their $\mathrm{CH}_{4} / \mathrm{Mn}$ ratio. In some cases the vents have much lower ratios than the plumes, probably because the vent fluids were collected with titanium syringes that leak gas, so that the gas concentrations are minimum values. In these cases the plume data have been used to categorize the site. The plume data have not been corrected for age and the accompanying preferential loss of $\mathrm{CH}_{4}$, but in most cases the values reported include plumes of near-zero age. For nonbuoyant plumes along seafloor spreading axes, the maximum concentration of Mn measured ranges from 2 to $100 \mathrm{nM}$ and the average concentration for the three groups increases hy less than threefold, from 22 to 38 to $61 \mathrm{nM}$, as the $\mathrm{CH}_{4} / \mathrm{Mn}$ ratio decreases from $>1$ to $<0.1$. Thus, most of the variation in the $\mathrm{CH}_{4} / \mathrm{Mn}$ ratio is due to variation in the concentration of $\mathrm{CH}_{4}$.

Eight sites have $\mathrm{CH}_{4} / \mathrm{Mn}>1$. Possible causes of high $\mathrm{CH}_{4}$ relative to $\mathrm{Mn}$ at these sites include (1) thermal decomposition of sedimentary organic matter at the Endeavour (Lilley et al., 1993), Guaymas Basin (Simoneit, 1983), and Okinawa Trough (Sakai et al., 1990; Gamo et al., 1991 ) sites; (2) active volcanism at the eruptive site on the EPR at $9^{\circ} 39$ to $53^{\prime} \mathrm{N}$ (this paper) and on Teahitia and Macdonald hotspot seamounts (Stuben et al., 1992), possibly accompanied by magma degassing; and (3) serpentinization reactions on the Mid-Atlantic Ridge near $15^{\circ} 05^{\prime} \mathrm{N}$ (Charlou et al., 1991b). Among back-arc spreading axes, the Okinawa Trough and the North Fiji Basin fall into this high- $\mathrm{CH}_{4} / \mathrm{Mn}$ group, the former because it is intracontinental and thus contains organic-rich sediment (Ishibashi et al., 1988), and the latter because its vents are vapor rich due to phase separation (Ishibashi et al., 1994).

More common are sites with $\mathrm{CH}_{4} / \mathrm{Mn}$ between 0.1 and 1 , of which fourteen were identified. These include sites along the mid-ocean ridge system on the Juan de Fuca, Gorda, Reykjanes, Mid-Atlantic, and Central Indian Ridges, the EPR near $13^{\circ}, 9-10^{\circ}$, and $20^{\circ} \mathrm{S}$, and the Galapagos Rift; shallow plumes along back-arc spreading axes in the Manus and North Fiji Basins; and Loihi Seamount, a hotspot seamount in Hawaii. These sites may represent "typical" $\mathrm{CH}_{4} / \mathrm{Mn}$ ratios, in which the $\mathrm{CH}_{4}$ originates by magmatic degassing, bacterial production, reaction between seawater and basalt, or some combination of these processes. Note that the nonsteady-state "event" plumes fall into this group, including the Megaplume I site on the Juan de Fuca Ridge at $44^{\circ} 48^{\prime} \mathrm{N}$ and the shallow plumes in the Manus and North Fiji Basins. The $\mathrm{CH}_{4}$ concentration in the hydrothermal plume at $63^{\circ} 06^{\prime} \mathrm{N}$ on the Reykjanes Ridge decreased from $108 \mathrm{nM}$ in 1990 , during a period of active eruption, to $18 \mathrm{nM}$ in 1993 (German et al., 1994; Palmer et al., 1995). While no Mn data are available for 1990 , it is likely that the $\mathrm{CH}_{4} / \mathrm{Mn}$ ratio was much higher during the eruption.

The third group has $\mathrm{CH}_{4} / \mathrm{Mn}$ ratios $<0.1$ and includes eight sites: Axial Seamount on the Juan de Fuca Ridge; the EPR near $21^{\circ}, 11^{\circ}$, and $9^{\circ} \mathrm{N}$; deep plumes along back-arc spreading axes in the Manus, North Fiji, and Lau Basins; and the site where lava enters the sea on the island of Hawaii. The Axial Seamount site includes only the high-salinity Inferno vent $(624 \mathrm{mmol} / \mathrm{kg} \mathrm{Cl})$; the low-salinity vents almost certainly have higher ratios, but $\mathrm{CH}_{4}$ data for them have not yet been published. The EPR sites in this low- $\mathrm{CH}_{4}$ group, including $21^{n} \mathrm{~N}$, the northern segment of our survey and the southernmost part of the southern segment, may be less active magmatically than those in the higher $\mathrm{CH}_{4}$ groups. In one case $\left(21^{\circ} \mathrm{N}\right)$ the vent waters are known to have achieved a steadystate composition (Campbell et al., 1988), in contrast to the rapid changes observed at the eruption site at $9^{\circ} 45$ to $52^{\prime} \mathrm{N}$ (Haymon et al., 1992). The deep (steady-state?) plumes at three back-arc basin sites also fall into this low- $\mathrm{CH}_{4} / \mathrm{Mn}$ group, whereas their shallow (episodic?) plumes fall into the intermediate group. Hydrothermal plumes formed where lava flows into the sea on the island of Hawaii have high concentrations of $\mathrm{H}_{2}$ but are virtually devoid of $\mathrm{CH}_{4}$ (Sansone et al., 1991).

In spite of the diversity of possible sources, $\mathrm{CH}_{4}$ is one of the most useful and sensitive indicators of hydrothermal activity on the seafloor. However, it is important that it be used in conjunction with other physical and chemical tracers. In fact, when used in this way, the ratio of $\mathrm{CH}_{4}$ to other tracers can provide critical information about the type of hydrothermal source that is present. More work is required to clarify the possible combinations. While the high $\mathrm{CH}_{4}$ concentrations and $\mathrm{CH}_{4} / \mathrm{Mn}$ ratios observed at $9^{\circ} 39$ to $53^{\prime} \mathrm{N}$ in our survey were clearly associated with a recent or ongoing volcanic eruption that produced low-salinity, gas-rich vents by subcritical phase separation, the actual source of the $\mathrm{CH}_{4}$, whether biogenic or from magma degassing, rock leaching, or water-rock reaction, is still unclear.

\section{CONCLUSIONS}

1) Real-time measurements of temperature and light attenuation in the water column, combined with shipboard measurements of dissolved $\mathrm{Mn}$ and $\mathrm{CH}_{4}$, are an efficient way to determine the distribution and relative intensity of hydrothermal venting along the mid-ocean ridge axis. These measurements also carry first-order information about the physical and chemical characteristics of the underlying hydrothermal systems, in part because dissolved Mn and $\mathrm{CH}_{4}$ behave nearly conservatively in very young nonbuoyant plumes along the axis. 
Table 1. Methane and Manganese in Hydrothermal Vents and Plumes

\begin{tabular}{|c|c|c|c|c|c|}
\hline Locality & $\begin{array}{c}\text { Plumes: } \\
\text { CH4 } \\
(\mathrm{nM})\end{array}$ & $\begin{array}{l}\mathrm{Mn} \\
(\mathrm{nM})\end{array}$ & $\begin{array}{l}\mathrm{CH} 4 / \mathrm{Mn} \\
\text { (molar) }\end{array}$ & $\begin{array}{l}\mathrm{CH} 4 / \mathrm{Mn} \\
\text { (molar) }\end{array}$ & Refs. \\
\hline \multicolumn{6}{|l|}{$\mathrm{CH} 4 / \mathrm{Mn}>1:$} \\
\hline \multicolumn{6}{|l|}{ Juan de Fuca Ridge } \\
\hline $48^{\circ} \mathrm{N}$ : Endeavour & 390 & 47 & $6-16$ & $4.3 \cdot 9.7$ & 1 \\
\hline Guaymas Basin & & & & $9-29$ & $\begin{array}{l}\text { Lilley et al. (1983) } \\
\text { Von Damm (1990) }\end{array}$ \\
\hline \multicolumn{6}{|l|}{ East Pacific Rise } \\
\hline $9^{\circ} 39^{\prime}-9^{\circ} 53^{\prime} N$ & 89 & 18 & 10.5 & & This paper \\
\hline Mid-Atlantic Ridge & & & & & Charlou et al. (1991) \\
\hline $15^{\circ} 05^{\prime} \mathrm{N}$ & 18 & 2.0 & 8.7 & & Charlou and Donval (1993) \\
\hline \multicolumn{6}{|l|}{ Back-arc spreading axes } \\
\hline Okinawa Trough & & & $0.6-3.2$ & & Ishibashi et al. (1988) \\
\hline N. Fiji Basin & & & & $1.7-2.5$ & Ishibashi et al. (1994) \\
\hline \multicolumn{6}{|l|}{ Hotspot seamounts } \\
\hline Teahitia Seamount & 14 & 60 & $0.013-10.6$ & & Stuben et al. (1992) \\
\hline Macdonald Seamount & 351 & 255 & $1.4-2.8$ & & Stuben et al. (1992) \\
\hline
\end{tabular}

\section{CH4/Mn 0.1-1:}

\begin{tabular}{|c|c|c|c|c|c|}
\hline \multicolumn{6}{|l|}{ Juan de Fuca Ridge } \\
\hline South Cleft & 3.0 & 27 & 0.11 & & Winn et al. (1986) \\
\hline Plume vent & & & & 0.023 & Charlou and Donval (1993) \\
\hline Vent 1 & & & & $0.036-0.045$ & Von Damm (1990) \\
\hline Megaplume I & & 90 & 0.29 & & Massoth (pers. comm.) \\
\hline North Cleft: 1986 & & & 0.78 & & Massoth (pers. comm.) \\
\hline North Cleft: 1987 & & & 0.45 & & Massoth (pers. comm.) \\
\hline Gorda Ridge: $42^{\circ} 45^{\prime} N$ & 5.1 & 9.7 & 0.53 & & Baker et al. (1987) \\
\hline \multicolumn{6}{|l|}{ East Pacific Rise } \\
\hline $13^{n} N$ & & & & & Charlou and Donval (1993) \\
\hline $12^{\circ} 47^{\prime}-12^{\circ} 51^{\prime} N$ & & & & $0.017-0.064$ & Von Damm (1990) \\
\hline $12^{\circ} 09^{\prime}-12^{\circ} 55^{\prime} \mathrm{N}$ & 8.1 & 38 & $0.12-0.26$ & & Charlou et al. (1991a) \\
\hline \multicolumn{6}{|l|}{$9-10^{\circ} \mathrm{N}$} \\
\hline $9^{\circ} 53^{\prime}-10^{\circ} 07^{\prime} N$ & 35 & 37 & 0.85 & & This paper \\
\hline $9^{\circ} 08^{\prime}-9^{\circ} 39^{\prime} \mathrm{N}$ & 33 & 24 & 0.51 & & This paper \\
\hline $19^{\circ} 25^{\prime S}$ & 11 & 85 & 0.13 & & $\operatorname{Kim}(1983)$ \\
\hline Galapagos Rift: $86^{\circ} \mathrm{W}$ & & & & $0.19-0.23$ & $\begin{array}{l}\text { Lilley et al. (1983) } \\
\text { Von Damm (1990) }\end{array}$ \\
\hline
\end{tabular}

2) We found hydrothermal venting along most of the ridge axis from $8^{\circ} 42^{\prime}$ to $11^{\circ} 51^{\prime} \mathrm{N}$. The least active sections surveyed were from $10^{\circ} 20$ to $52^{\prime} \mathrm{N}$ and the OSCs at $9^{\circ} 03^{\prime} \mathrm{N}$ and especially that at $11^{\circ} 45^{\prime} \mathrm{N}$. Even on these sections, however, weak $\mathrm{Mn}$ and $\mathrm{CH}_{4}$ plumes were found that probably originated locally. Both OSCs had chemically detectable hydrothermal plumes not only over the magmatically robust limbs, but also over the limbs thought to be relatively magma starved. Both nodal basins had hydrothermal plumes that originated on the axis and were trans- ported over the basins, along with relatively high concentrations of $\mathrm{Mn}$ and $\mathrm{CH}_{4}$ that persisted to the deep basin floors.

3) The height of plume rise, as estimated from the depth of maximum concentrations of $\mathrm{Mn}$ and $\mathrm{CH}_{4}$, varied from $70-290 \mathrm{~m}$ above the seafloor on the northern segment and $20-310 \mathrm{~m}$ on the southern segment. In general, however, the plumes rose higher on the southern segment. In addition to maxima well above the seafloor, high concentrations of $\mathrm{Mn}$ and $\mathrm{CH}_{4}$ persisted to near the seafloor on the 


\begin{tabular}{|c|c|c|c|c|c|}
\hline \multicolumn{6}{|l|}{ Mid-Atlantic Ridge } \\
\hline $63^{\circ} 06^{\prime} \mathrm{N}$ : Reykjanes R. & 18 & 60 & 0.30 & & German et al. (1994) \\
\hline \multicolumn{4}{|l|}{$26^{\circ} 08^{\prime} \mathrm{N}:$ TAG } & \multirow[t]{4}{*}{$0.15-0.24$} & Charlou et al. (1991b) \\
\hline Buoyant plume & 67,3 & 7420 & $0.079-0.12$ & & Charlou and Donval (1993) \\
\hline \multirow[t]{2}{*}{ Non-buoyant plume } & 9.4 & 36 & $0.26-0.28$ & & Von Damm (1990) \\
\hline & & & & & Rudnicki and Elderfield (1992) \\
\hline \multicolumn{4}{|l|}{$23^{\circ} 22^{\prime} \mathrm{N}$ : MARK } & \multirow[t]{2}{*}{$0.09-0.14$} & \multirow[t]{2}{*}{ Charlou and Donval (1993) } \\
\hline Buoyant plume & 327 & 3850 & $0.074-0.13$ & & \\
\hline \multicolumn{3}{|l|}{ Central Indian Ridge } & $0.22-0.41$ & \multicolumn{2}{|r|}{ Pluger et al. (1990) } \\
\hline \multicolumn{6}{|l|}{ Back-arc spreading axes } \\
\hline \multicolumn{6}{|l|}{ East Manus Basin } \\
\hline Shallow plume & \multirow[t]{2}{*}{6.5} & \multirow[t]{2}{*}{20} & 0.29 & \multirow{2}{*}{\multicolumn{2}{|c|}{$\begin{array}{l}\text { Gamo et al. (1993) } \\
\text { Gamo et al. (1993) }\end{array}$}} \\
\hline Central Manus Basin & & & 0.26 & & \\
\hline \multicolumn{6}{|l|}{ North Fiji Basin } \\
\hline Shallow plume & 4.2 & 12 & $0.24-0.39$ & \multicolumn{2}{|r|}{ Nojiri et al. (1989) } \\
\hline \multicolumn{6}{|l|}{ Hotspot seamounts } \\
\hline Loihi Seamount & 292 & $1 \uparrow 00$ & $0.26-0.33$ & 0.34 & $\begin{array}{l}\text { Sakai et al. (1987) } \\
\text { Karl et al. (1988) }\end{array}$ \\
\hline \multicolumn{6}{|l|}{$\mathrm{CH} 4 / \mathrm{Mn}<0.1:$} \\
\hline \multicolumn{6}{|c|}{ Juan de Fuca Ridge } \\
\hline $46^{\circ} \mathrm{N}$ : Axial Seamount: & erno ve & & & 0.022 & Butterfield et al. (1990) \\
\hline \multicolumn{4}{|l|}{ East Pacific Rise } & \multirow{2}{*}{\multicolumn{2}{|c|}{$\begin{array}{l}\text { Lilley et al. }(1983,1993) \\
\text { Von Damm }(1990)\end{array}$}} \\
\hline $21^{\circ} \mathrm{N}$ & 2.7 & 59 & 0.045 & & \\
\hline \multicolumn{4}{|l|}{$11^{\circ} \mathrm{N}$} & \multicolumn{2}{|r|}{ Charlou and Donval (1993) } \\
\hline \multicolumn{4}{|l|}{$10^{\circ} 57^{\prime}-11^{\circ} 15^{\prime} \mathrm{N}$} & \multirow[t]{2}{*}{$0.072-0.17$} & Von Damm (1990) \\
\hline $10^{\circ} 30^{\prime}-11^{\circ} 52^{\prime} \mathrm{N}$ & 5.9 & 76 & 0.075 & & This paper \\
\hline $9-10^{\circ} \mathrm{N}$ & & & & & \\
\hline $8^{\circ} 42^{\prime}-9^{\circ} 08^{\prime} \mathrm{N}$ & 5.5 & 42 & 0.069 & & This paper \\
\hline Back-arc spreading axes & & & & & \\
\hline East Manus Basin & & & & & \\
\hline Deep plume & 4.3 & 100 & $0.02 \cdot 0.05$ & & Gamo et al. (1993) \\
\hline North Fiji Basin & & & & & \\
\hline Deөp plume & 1.6 & 28 & 0.056 & & Nojiri et al. (1989) \\
\hline Lau Basin & & & & $0.0005-0.0008$ & $\begin{array}{l}\text { Charlou and Donval (1993) } \\
\text { Fouquet et al. (1991) }\end{array}$ \\
\hline Hotspot seamounts & & & & & \\
\hline Hawaii island & 0 & 310 & 0 & & Sansone et al. (1991) \\
\hline
\end{tabular}

1. De Angelis et al. (1993), Kadko et al. (1990), Lilley et al. (1993), Gamo et al. (1993), Butterfield et al. (1994)

northern segment, but not on the southern. This low-lying hydrothermal cloud probably resulted from diffuse venting at lower temperatures, of solutions rich in both $\mathrm{Mn}$ and $\mathrm{CH}_{4}$; such venting may be more abundant on the northern segment than on the southern.

4) On the northern segment, the physical and chemical tracers all correlated positively and linearly with one another, suggesting that the segment was fed by relatively uniform hydrothermal endmember fluids with a mean $\mathrm{CH}_{4} / \mathrm{Mn}$ molar ratio of 0.075 . Alternatively, these fluids could have been homogenized within the plumes. As light attenuation also correlated with particle mass concentration (Baker et al., 1994) and the particles were mainly Fe oxyhydroxides, Fe sulfides, and silica (Feely et al., 1994), the endmember solutions feeding the vents and plumes probably had relatively uniform concentrations of $\mathrm{Fe}, \mathrm{S}$, and $\mathrm{Si}$, as well as $\mathrm{Mn}$ and $\mathrm{CH}_{4}$, all along the segment.

5) On the southern segment, the $\mathrm{Mn}$ and $\mathrm{CH}_{4}$ plumes were decoupled and the $\mathrm{CH}_{4} / \mathrm{Mn}$ molar ratio varied drastically and systematically with latitude, chiefly as a result of variation in $\mathrm{CH}_{4}$. The $\mathrm{CH}_{4}$ concentration was much higher on the southern segment than on the northern, but Mn con- 
centrations were about the same. The section from $8^{\circ} 42^{\prime}$ to $9^{\circ} 08^{\prime} \mathrm{N}$, with $\mathrm{CH}_{4} / \mathrm{Mn}$ of 0.069 , closely resembled the northern segment. The sections from $9^{\circ} 08$ to $39^{\prime} \mathrm{N}$ and $9^{\circ} 53^{\prime}$ to $10^{\circ} 07^{\prime} \mathrm{N}$ resembled one another and had the highest Mn concentrations on the southern segment, with $\mathrm{CH}_{4} /$ $\mathrm{Mn}$ of 0.74 . The section from $9^{\circ} 39$ to $53^{\prime} \mathrm{N}$ had by far the highest $\mathrm{CH}_{4}$ concentrations, with $\mathrm{CH}_{4} / \mathrm{Mn}$ as high as 10 . The most $\mathrm{CH}_{4}$-rich plumes varied widely in their rise height. This section was the site of a volcanic eruption only seven months prior to our cruise.

6) On the southern segment correlations among plume tracers were complex. Unlike on the northern segment, no strong temperalure dependence was evident, but $\mathrm{CH}_{4}$ did vary positively with light attenuation, which in turn was unrelated to particle mass concentration (Baker et al., 1994). The particle population was dominated instead by S-rich organic particles (Feely et al., 1994).

7) The complexities of plumes on the southern segment can be explained as resulting from the volcanic eruption. This eruption was accompanied by subcritical phase separation that produced extreme variations in chloride and gas concentrations in the venting fluids. Temperature, Mn, and $\mathrm{CH}_{4}$ were decoupled because $\mathrm{Mn}$ and other metals would be enriched in the hot brines, whereas $\mathrm{CH}_{4}$ would be enriched in the hot vapor phase. The vapor phase carried abundant bacterial particles, probably explaining the correlation between $\mathrm{CH}_{4}$ and light attenuation. It vented as both diffuse and focused flow, through holes, cracks, and pits in new lava flows and rubble rather than through sulfide chimneys, thereby accounting for the large variation in rise height of the most $\mathrm{CH}_{4}$-rich plumes.

8) $\mathrm{CH}_{4} / \mathrm{Mn}$ molar ratios in submarine hydrothermal vents and plumes from around the world vary over more than four orders of magnitude, from $<0.001$ to $>10$. High ratios have been attributed to several causes, including thermal decomposition of organic matter, serpentinization reactions, and active volcanism, although the actual origin of $\mathrm{CH}_{4}$ in the latter case is not clear. Low ratios may occur at sites that are less magmatically active, where the venting solutions have reached a steady-state composition.

Acknowledgments-Special thanks are due to Karen Selph, Ursula Ginster, and Chris Measures, who assisted with operations and analyses at sea, and the officers and crew of the New Horizon. Thanks also to J. L. Charlou, T. Gamo, and especially G. J. Massoth, who, along with three anonymous persons, reviewed either this or an earlier version of the manuscript. This research was supported by grants OCE90-20405 (to MJM) from the U.S. National Science Foundation and N00014-90-J-1805 (to FJS) from the Office of Naval Research, and by the VENTS Program of the National Oceanic and Atmospheric Administration. This is contribution number 3934 from the School of Ocean and Earth Science and Technology of the University of Hawaii.

Editorial handling: L. S. Balistrieri

\section{REFERENCES}

Baker E. T. et al. (1987) Evidence for high-temperature hydrothermal venting on the Gorda Ridge, northeast Pacific Ocean. Deep. Sea Res. 34, 1461-1476.
Baker E. T. et al. ( 1994) Hydrothermal plumes along the East Pacific Rise, $8^{\circ} 40^{\prime}$ to $11^{\circ} 50^{\prime} \mathrm{N}$ : Plume distribution and relationship to the apparent magmatic budget. Earth Planet. Sci. Lett. 128, 1-17.

Ballard R. D., Hekinian R., and Francheteau J. (1984) Geological setting of hydrothermal activity at $12^{\circ} 50^{\prime} \mathrm{N}$ on the East Pacific Rise: A submersible study. Earth Planet. Sci. Lett. 69, 176-186.

Ballard R. D. et al. (1988) Geological mapping of the East Pacific Rise axis $\left(10^{\circ} 19^{\prime}-11^{\circ} 53^{\prime} \mathrm{N}\right)$ using the Argo and ANGUS mapping systems. Canadian Mineral. 26, 467-486.

Baross J. A., Lilley M. D., and Gordon L. I. (1982) Is the $\mathrm{CH}_{4}, \mathrm{H}_{2}$ and $\mathrm{CO}$ venting from submarine hydrothermal systems produced by thermophilic bacteria? Nature 298, 366-368.

Brooks J. M., Reid D. F., and Bernard B. B. (1981) Methane in the upper water column of the northwestern Gulf of Mexico. J. Geophys. Res. 86, $11029-11040$.

Butterfield D. A., Massoth G. J., McDuff R. E., Lupton J. E., and Lilley M. D. (1990) Geochemistry of hydrothermal fluids from Axial Seamount hydrothermal emissions study vent field, Juan de Fuca Ridge: Subseafloor boiling and subsequent fluid-rock interaction. J. Geophys. Res. 95, 12895-12921.

Rutterfield D. A., McDuff R. E., Mottl M. J., Lilley M. D., Lupton J. E., and Massoth G. J. (1994) Gradients in the composition of hydrothermal fluids from the Endeavour segment vent field: Phase separation and brine loss. J. Geophys. Res. 99, 9561-9583.

Campbell A. C., Bowers T. S., Measures C. I., Falkner K. K., Khadem M., and Edmond J. M. (1988) A time series of vent fluid compositions from $21^{\circ} \mathrm{N}$, East Pacific Rise $(1979,1981,1985)$, and the Guaymas Basin, Gulf of California $(1981,1985)$. J. Geophys. Res. 93, 4537-4549.

Charlou J. L. and Donval J. P. ( 1993) Hydrothermal methane venting between $12^{\circ} \mathrm{N}$ and $26^{\circ} \mathrm{N}$ along the Mid-Atlantic Ridge. J. Geophys. Res. 98, 9625-9642.

Charlou J. L., Bougault H., Appriou P., Jean-Baptiste P., Etoubleau J., and Birolleau A. (1991a) Water column anomalies associated with hydrothermal activity between $11^{\circ} 40^{\prime}$ and $13^{\circ} \mathrm{N}$ on the East Pacific Rise: Discrepancies between tracers. Deep-Sea Res. 38, $569-596$.

Charlou J. L., Bougault H., Appriou P., Nelson T., and Rona P. (1991b) Different $\mathrm{TDM} / \mathrm{CH}_{4}$ hydrothermal plume signatures: TAG site at $26^{\circ} \mathrm{N}$ and serpentinized ultrabasic diapir at $15^{\circ} 05^{\prime} \mathrm{N}$ on the Mid-Atlantic Ridge. Geochim. Cosmochim. Acta 55, 32093222.

Cowen J. P., Massoth G. J., and Feely R. A. (1990) Scavenging rates of dissolved manganese in a hydrothermal vent plume. Deep-Sea Res. 37, 1619-1637.

Davis E. E. et al. ( 1993) Proc. ODP, Init. Repts. 139. College Station, Texas (Ocean Drilling Program).

De Angelis M. A., Lilley M. D., Olson E. J., and Baross J. A. (1993) Mcthane oxidation in deep-sca hydrothermal plumes of the Endeavour segment of the Juan de Fuca Ridge. Deep-Sea Res. 40, 1169-1186.

Detrick R. S. et al. (1987) Multichannel imaging of a crustal magma chamber along the East Pacific Rise. Nature 326, 35-41.

Feely R. A., Gendron J. F., Baker E. T., and Lebon G. T. (1994) Hydrothermal plumes along the East Pacific Rise, $8^{\circ} 40^{\prime}$ to $11^{\circ} 50^{\prime} \mathrm{N}$ : Particle distribution and composition. Earth Planet. Sci. Lett. 128, 19-36.

Fouquet Y. et al. (1991) Hydrothermal activity in the Lau back-arc basin: sulfides and water chemistry. Geology 19, 303-306.

Gamo T., Sakai H., Kim E.-S., Shitashima K., and Ishibashi J. (1991) High alkalinity due to sulfate reduction in the CLAM hydrothermal field, Okinawa Trough. Earth Planet. Sci. Lett. 107, 328-338.

Gamo T. et al. (1993) Hydrothermal plumes in the eastern Manus Basin, Bismarck Sea: $\mathrm{CH}_{4}, \mathrm{Mn}, \mathrm{Al}$, and $\mathrm{pH}$ anomalies. Deep-Sea Res. 40, 2335-2349.

German C. R. et al. (1994) Hydrothermal activity on the Reykjanes Ridge: The Steinaholl vent-field at $63^{\circ} 06^{\prime}$ N. Earth Planet. Sci. Lett. 121, 647-654.

Haymon R. M., Fornari D. J., Edwards M. H., Carbotte S., Wright D., and Macdonald K. C. (1991) Hydrothermal vent distribution along the East Pacific Rise crest ( $\left.9^{\circ} 09^{\prime}-54^{\prime} \mathrm{N}\right)$ and its relationship to magmatic and tectonic processes on fast-spreading mid-ocean ridges. Earth Planet. Sci. Lett. 104, 513-534. 
Haymon R. et al. (1992) Dramatic short-term changes observed during March ' 92 dives to April '91 eruption site on the East Pacific Rise Crest, 9 ${ }^{\circ} 45-52^{\prime}$ N. Eos 73, 524 (abst.).

Haymon R. M. et al. ( 1993) Volcanic eruption of the mid-ocean ridge along the East Pacific Rise crest at $9^{\circ} 45-52^{\prime}$ N: Direct submersible observations of seafloor phenomena associated with an eruption event in April, 1991. Earth Planet. Sci. Lett. 119, 85-101.

Ishibashi J-I. et al. (1988) Geochemical evidence for hydrothermal activity in the Okinawa Trough. Geochem. J. 22, 107-114.

Ishibashi J-I. et al. (1994) Helium and carbon geochemistry of hy drothermal fluids from the North Fiji Basin spreading ridge (Southwest Pacific). Earth Planet. Sci. Lett. 128, 183-197.

Jannasch H. W. and Mottl M. J. (1985) Geomicrobiology of deepsea hydrothermal vents. Science 229, 717-725.

Kadko D. C., Rosenberg N. D., Lupton J. E., Collier R. W., and Lilley M. D. (1990) Chemical reaction rates and entrainment within the Endeavour Ridge hydrothermal plume. Earth Planet. Sci. Lett. 99, 315-335.

Karl D. M., McMurtry G. M., Malahoff A., and Garcia M. O. (1988) Loihi Seamount, Hawaii: a mid-plate volcano with a distinctive hydrothermal system. Nature 335, 532-535.

Kastens K. A., Ryan W. B. F., and Fox P. J. (1986) Structural and volcanic expression of a fast slipping ridge-transform-ridge-plate boundary: SeaMARC I and photographic surveys at the Clipperton transform fault. J. Geophys. Res. 91, 3469-3488.

Kim K.-R. (1983) Methane and radioactive isotopes in submarine hydrothermal systems. Ph.D. dissertation, Univ. California.

Lavelle J. W., Cowen J. P., and Massoth G. J. (1992) A model for the deposition of hydrothermal manganese near ridge crests. $J$. Geophys. Res. 97, 7413-7427.

Lilley M. D., Baross J. A., and Gordon L. I. (1983) Reduced gases and bacteria in hydrothermal fluids: The Galapagos spreading center and $21^{\circ} \mathrm{N}$ East Pacific Rise. In Hydrothermal Processes at Seafloor Spreading Centers (ed. P. A. Rona et al.), pp. 411-449. Plenum Press.

Lilley M. D., Olson E. J., McLaughlin E., and Von Damm K. L. (1991) Methane, hydrogen and carbon dioxide in vent fluids from the $9^{\circ} \mathrm{N}$ hydrothermal system. Eos 72, 481 (abstr.).

Lilley M. D., Olson E. J., Lupton J. E., and Von Damm K. L. (1992) Volatiles in the $9^{\circ} \mathrm{N}$ hydrothermal system: a comparison of 1991 and 1992 data. Eos 73, 524 (abstr.).

Lilley M. D., Butterfield D. A., Olson E. J., Lupton J. E., Macko S. A., and McDuff R. E. (1993) Anomalous $\mathrm{CH}_{4}$ and $\mathrm{NH}_{4}^{+}$concentrations at an unsedimented mid-ocean-ridge hydrothermal system. Nature 364, 45-47.

Lupton J. E. et al. ( 1993) Chemical and physical diversity of hydrothermal plumes along the East Pacific Rise, $8^{\circ} 45^{\prime} \mathrm{N}$ to $11^{\circ} 50^{\prime} \mathrm{N}$. Geophys. Res. Lett. 20, 2913-2916.

Macdonald K. C. and Fox P. J. (1988) The axial summit graben and cross-sectional shape of the East Pacific Rise as indicators of axial magma chambers and recent volcanic eruptions. Earth Planet. Sci. Lett. 88, 119-131.

Macdonald K. C., Sempere J.-C., and Fox P. J. ( 1984) East Pacific Rise from Siqueiros to Orozco fracture zones: Along-strike continuity of axial neovolcanic zone and structure and evolution of overlapping spreading centers. J. Geophys. Res. 89, 6049-6069.

Mandernack K. W. and Tebo B. M. (1993) Manganese scavenging and oxidation at hydrothermal vents and in vent plumes. Geochim. Cosmochim. Acta 57, 3907-3923.

Massoth G. J., Butterfield D. A., Lupton J. E., McDuff R. E., Lilley M. D., and Jonasson I. R. (1989) Submarine venting of phaseseparated hydrothermal fluids at Axial Volcano, Juan de Fuca Ridge. Nature 340, 702-705.
Massoth G. J. et al. (1994) Temporal and spatial variability of hydrothermal manganese and iron at Cleft segment, Juan de Fuca Ridge. J. Geophys. Res. 99, 4905-4923.

McConachy T. F., Ballard R. D., Mottl M. J., and Von Herzen R. P. (1986) Geologic form and setting of a hydrothermal vent field at lat $10^{\circ} 56^{\prime} \mathrm{N}$, East Pacific Rise: A detailed study using $A N G U S$ and Alvin. Geology 14, 295-298.

Nojiri Y., Ishibashi J., Kawai T., Otsuki A., and Sakai H. (1989) Hydrothermal plumes along the North Fiji Basin spreading axis. Nature 342, 667-670.

Palmer M. R., Ludford E. M., German C. R., and Lilley M. D. (1995) Dissolved methane and hydrogen in the Steinaholl hydrothermal plume, Reykjanes Ridge. Geol. Soc. London Spec. Publ. (in press).

Plüger W. L. et al. (1990) Discovery of hydrothermal fields at the Central Indian Ridge. Mar. Min. 9, 73-86.

Resing J. A. and Mottl M. J. (1992) Determination of manganese in seawater using flow injection analysis with on-line preconcentration and spectrophotometric detection. Anal. Chem. 64, 26822687.

Rona P. A. and Speer K. G. (1989) An Atlantic hydrothermal plume: Trans-Atlantic Geotraverse (TAG) area, Mid-Atlantic Ridge crest near $26^{\circ}$ N. J. Geophys. Res. 94, 13879-13893.

Rona P. A. and Trivett D. A. (1992) Discrete and diffuse heat transfer at ASHES vent field, Axial Volcano, Juan de Fuca Ridge. Earth Planet. Sci. Lett. 109, 57-71.

Rudnicki M. D. and Elderfield H. (1992) Helium, radon and manganese at the TAG and Snakepit hydrothermal fields $26^{\circ}$ and $23^{\circ} \mathrm{N}$, Mid-Atlantic Ridge. Earth Planet. Sci. Lett. 113, 307-321.

Sakai H. et al. (1987) Hydrothermal activity on the summit of Loihi Seamount, Hawaii. Geochem. J. 21, 11-21.

Sakai H. et al. ( 1990) Unique chemistry of the hydrothermal solution in the Mid-Okinawa Trough back-arc basin. Geophys. Res. Lett. 17, 2133-2136

Sansone F. J., Resing J. A., Tribble G. W., Sedwick P. N., Kelly K. M., and Hon K. (1991) Lava-seawater interactions at shallowwater submarine lava flows. Geophys. Res. Lett. 18, 1731-1734.

Scheirer D. S. and Macdonald K. C. (1993) Variation in cross-sectional area of the axial ridge along the East Pacific Rise: Evidence for the magmatic budget of a fast spreading center. J. Geophys. Res. 98, 7871-7875.

Sempere J.-C. and Macdonald K. C. (1986) Deep-tow studies of the overlapping spreading center at $9^{\circ} 03^{\prime} \mathrm{N}$ on the East Pacific Rise. Tectonics 5, 881-900.

Simoneit B. R. T. (1983) Effects of hydrothermal activity on sedimentary organic matter: Guaymas Basin, Gulf of California-petroleum genesis and protokerogen deradation. In Hydrothermal Processes at Seafloor Spreading Centers (ed. P. A. Rona et al.), pp. 451-471. Plenum Press.

Stuben D. et al. (1992) Manganese, methane, iron, zinc, and nickel anomalies in hydrothermal plumes from Teahitia and Macdonald volcanoes. Geochim. Cosmochim. Acta 56, 3693-3704.

Von Damm K. L. (1990) Seafloor hydrothermal activity: black smoker chemistry and chimneys. Ann. Rev. Earth Planet. Sci. 18, 173-204.

Von Damm K. L. et al. (1995) Evolution of East Pacific Rise hydrothermal vent fluids following a volcanic eruption. Nature 375, 4750.

Welhan J. A. (1988) Origins of methane in hydrothermal systems. Chem. Geol. 71, 183-198.

Winn C. D., Karl D. M., and Massoth G. J. (1986) Microorganisms in deep-sea hydrothermal plumes. Nature 320, 744-746. 